\title{
Unemployment Insurance, Trade Unions and the Strange Case of the Israeli Labour Movement ${ }^{*}$
}

\author{
JOHN GAL
}

Summary: The goal of this paper is to investigate the relationship between the labour movement and unemployment insurance (UI). Following a brief overview of the evolution of the approach of labour movements towards UI, the focus shifts to an analysis of a case study of the Israeli labour movement. The study traces the development of the approach of this movement towards UI during the pre-state period and following the establishment of Israel. It indicates that, while the policy adopted by the Israeli labour movement in the pre-state period was similar to that of other labour movements, the motivation differed in that the goals of the Israeli movement were primarily nationalist. In the post-independence period, the labour movement objected to the adoption of UI and prevented the introduction of this programme for two decades. The reasons for this are linked to the values and perceptions of the labour movement leadership and the legacies of policies adopted during the pre-state period.

\section{INTRODUCTION}

Compulsory state administered unemployment insurance programmes are generally regarded today as a core component of any welfare state. ${ }^{1}$ Indeed, a country which lacks a comprehensive programme aimed at providing adequate social security to the unemployed would more than likely not be regarded as a welfare state by most observers. In a period during which the welfare state is still under attack by a powerful coalition of political forces, labour movements have tended to take the role of the most tenacious defendants of UI. Thus, given the fact that the earliest

- The research on this paper was supported by a grant from the Lavon Institute. I am grateful to Yitshak Eylam (Finkelstein) for a long interview he granted me as part of my research efforts. I am also grateful for the comments of three anonymous referees.

1 The literature dealing with contemporary unemployment insurance and the role of this programme in the welfare state is extensive. See, for example, S.J. Blaustein and I. Craig, An International Review of Unemployment Insurance Schemes (Kalamazoo, 1977); F. Calceon, L. Eeckhoudt and D. Greiner, "Unemployment Insurance, Social Protection and Employment Policy: An Intemational Comparison", International Social Security Review, 15 (1988), pp. 119-134; ILO, Social Security for the Unemplojed (Geneva, 1976); G. Schmid, B. Reissert and G. Buche, Unemployment Insurance and Active Labour Market Policy (Detroit, 1992).

International Review of Social History 42 (1997), pp. 357-396 
programmes aimed at providing a degree of social protection for the unemployed in capitalist societies were established by trade unions, the tendency to identify the labour movement with UI should not come as a surprise. Indeed in one of the few quantitative comparative analyses of the adoption of UI in welfare states, Jens Alber found that labour-led governments were more prone to establish UI programmes than those led by conservatives or liberals. ${ }^{2}$

While a closer look at the involvement of various labour movements in the development of protection for the unemployed indicates that, in fact, the position on unemployment insurance was far less clear-cut, it is true that by the end of World War II, West European and North American labour movements generally supported compulsory state unemployment insurance programmes of one form or another.

The Israeli case presents an extraordinary contrast to this trend. In the early 1950s, it would appear that the conditions for the introduction of UI were ripe. With the achievement of statehood in 1948, the political wing of the labour movement, the Mapai party, had taken power, and its trade union federation, the Histadrut, was all-powerful. The union federation had a history of involvement in activity aimed at providing for the unemployed, including the establishment of a union unemployment fund during the 1930s, and in 1950 a governmental committee on social security recommended the introduction of a compulsory state unemployment insur-

2 J. Alber, "Government Responses to the Challenge of Unemployment: The Development of Unemployment Insurance in Westem Europe", in P. Flora and A. Heidenheimer (eds), The Development of Welfare States in Europe and America (New Brunswick, 1981), pp. 151-183. For other studies that describe the role of labour movements in policy debates over unemployment insurance, see H. Heclo, Modern Social Politics in Britain and Sweden (New Haven, 1974); L.A. Pal, State, Class, and Bureaucracy (Kingston, 1987); D. Nelson, Unemployment Insurance: The American Experience 1915-1935 (Madison, 1989); B. Weisbrod, "The Crisis of German Unemployment Insurance in 1928/1929 and its Political Repercussions", in W.J. Mommsen and W. Mock (eds), The Emergence of the Welfare State in Britain and Germany (London, 1981), pp. 188-204; G. Therbom, The Working Class and the Welfare State, paper presented to the 5th Nordic Congress of Research in the History of the Labour Movement, Murikka, 1983; G. Vanthemsche, "Unemployment Insurance in Interwar Belgium", International Review of Social History, 35 (1990), pp. 349-376. These findings dovetail nicely with a fundamental claim of one of the dominant approaches to analysis of the welfare state, the "social-democratic" or "power-resources" approach, which posits that labour movements were early and forceful advocates of state involvement in social protection and that universalistic, decommodifying welfare states catering to a wide variety of social needs emerged in societies in which the working class was large, well organized and united in trade unions and social-democratic political parties. For good critical overviews of this approach, see G. Esping-Andersen and $K$. van Kersbergen. "Contemporary Research on Social Democracy", Annual Review of Sociology. 18 (1992), pp. 187-208; C. Pierson, Beyond the Welfare State (Cambridge, 1991), pp. 2439: M. Shalev, "The Social Democratic Model and Beyond", Comparative Social Research, 6 (1983), pp. 315-351. For a more biting critique of this approach to historical analysis, see P. Baldwin. "The Scandinavian Origins of the Social Interpretation of the Welfare State", Comparative Studies of History and Society, 31 (1989), pp. 3-24. 
ance programme. Yet, despite all these developments, the labour movement leadership refused to introduce UI of any kind and maintained its opposition to the idea for the next two decades.

The aim of this paper is to understand the Israeli labour movement's refusal to adopt unemployment insurance and the implications of this position. While the emergence of UI in Israel and assistance to the unemployed in the period prior to the establishment of the state have been the subject of a small number of studies, none of these has attempted to view the development of this form of social security in a historical perspective that takes into account (and links) developments in both periods within the labour movement. ${ }^{3}$

In order to establish a comparative context for the study, the following section will present a brief overview of the historical development of the approach of labour movements in industrialized societies towards UI. After that, the focus will shift to the specific case of the Israeli labour movement and its approach to $U I$ in the pre-state period. Following a short description of developments in the labour market in pre-state Palestine and the role of the Histadrut in it, the trade union federation's efforts to establish a UI programme of its own during the 1930s will be examined. Later, the impact of this effort on the policies of the Histadrut and of Mapai, the dominant political force in the labour movement and in Israel as a whole, during the period after independence will be described. It will be claimed that the labour movement leadership's experience of dealing with unemployment during the 1920s structured its policies on this issue in the 1930s and that subsequently the results of these policies during a recession in the late 1930s strongly influenced its opposition to UI after independence.

A primary component in the proposed explanation for the unique response of the Israeli labour movement to proposals to introduce $\mathrm{UI}$ in the early 1950s, then, will be the notion of "policy feedbacks" or "policy legacies". Adopting a sequential view of social policy development,

${ }^{3}$ For an examination of assistance to the unemployed in the pre-state period, see $R$. Schindler, "Unemployment Assistance During the Period of the Yishuv: Philanthropy, Productivity and Mutual Aid" , Journal of Jewish Community Service, 52 (1977), pp. 356361. An unpublished thesis on the Histadrut's efforts to deal with unemployment during this period was written by E. Rosenthal, "Hoser Avodah-Hitgabshut Emdot, Midinyut U'naase Betnuat Haavodah" (unpublished thesis, Tel Aviv University, 1976). On the development of UI after the establishment of Israel, see A. Doron and R. Kramer, The Welfare State in Israel (Boulder, 1991); J. Gal, "The Development of Unemployment Insurance in Israel", Social Security, 3 (1994), pp. 117-136; and M. Shalev, Labour and the Political Economy in Israel (Oxford, 1992).

"See P. Pierson, "When Effect Becomes Cause", World Politics, 45 (July 1993), pp. 595628, and T. Skocpol and E. Amenta, "States and Social Policies", Annual Revicuv of Sociology, 12 (1986). pp. 131-157. This notion has also formed a part of the historical institutionalist approach in comparative politics as defined in S. Steinmo, K. Thelen and F. Longstreth (eds), Structuring Politics (Cambridge, 1992). 
Theda Skocpol and others have shown that previous social policies can have a major impact on the nature of the debate over social policy and politics at a later stage. Once enacted, policies tend to redefine agendas and their results determine the future actions of decision-makers, interest groups or the public as a whole. As a result, rather than being an objective, original response to needs that have arisen, social policy will tend to reflect the reaction, either positive or negative, of individuals or groups to previous policies or the constraints that institutions established by previous policies have created.

\section{TRADE UNIONS AND UNEMPLOYMENT INSURANCE - AN OVERVIEW}

Trade unions and friendly societies were the first organizations to attempt to establish unemployment funds for workers unable to find employment, thereby continuing a tradition of mutual aid and the provision of financial support for out-of-work members established by medieval guilds. ${ }^{6}$ In the first decades of the nineteenth century, this form of assistance to the unemployed further developed and was linked to the tramping system, by which unemployed workers took to the road seeking work away from their local area. $^{7}$

By the middle of the nineteenth century (and, in certain cases, even beforehand) more static systems of mutual aid for the unemployed were beginning to be adopted by unions. ${ }^{8}$ The rapid development of trade union-

3 The notions of sequential approaches to policies and to developments within societies was formulated explicitly by S. Verba, "Sequences and Development", in L. Binder et al. (eds), Crises and Sequences in Political Development (Princeton, 1971), pp. 283-316. For examples of the use of this explanation, see S. Kuhnle, "The Growth of Social Insurance Programs in Scandinavia: Outside Influences and Internal Forces", in Flora and Heidenheimer, Development of Welfare States in Europe and America, pp. 125-150; T. Skocpol, Protecting Soldiers and Mothers (Cambridge, MA, 1992) and idem, "The Limits of the New Deal System and the Roots of Contemporary Welfare Dilemmas", in M. Weir, A.S. Orloff and T. Skocpol (eds), The Politics of Social Policy in the Unitcd States (Princeton, 1988), pp. 293-317.

- See C. Kiehel, Unemployment Insurance in Belgium (New York, 1932).

7 For an analysis of the tramping system, see E. Hobsbawm, Labouring Men (London, 1964), pp. 34-63 and for graphic descriptions of the workings of this system based on personal diaries, see J. Burnett, Jdle Hands (London, 1994), pp. 111-115.

- The Journeymen Steam-Engine Makers' Society in Britain was the first union to do so. It was organized in 1824 and from then on provided its members with a travelling allowance, a funeral benefit and compensation in case of accidental disablement in addition to out-of-work pay. In 1850 it joined other organizations to form the Amalgamated Society of Engineers, Machinists, Smiths, Millwrights and Patternmakers, which paid out-of-work pay to unemployed members for a period of six months during a labour dispute in 1852. An additional pioneering step in this regard was taken by the foundrymen's union, which introduced a fund for unemployed members in 1831. For more on these and other early union unemployment funds, see M.B. Gilson, Unemployment Insurance in Great Britain (New York, 1931); J. Harris, Unemployment and Politics (Oxford, 1972), pp. 295-298 and 
ism in many west and central European countries and the constant threat of unemployment led to the proliferation of the notion of union unemployment funds. In Germany, where union organization was particularly advanced, 15 of the 46 central worker's associations provided voluntary support for unemployed members by the year $1894 .^{9}$ By the end of the first decade of the twentieth century, 2.4 million workers were covered by union unemployment plans in Britain and similar funds existed in Belgium, Denmark, France, Norway, Sweden, Switzerland and the United States. ${ }^{10}$

The union funds not only provided a solution, if sometimes very limited, to the needs of out-of-work union members, but they were also an incentive for new members and a means with which to reduce the wage depressing effect of a "reserve army" of unemployed workers, thereby protecting the employed as well." "Moreover, the funds were a facet in the socialist unions' attempts to provide members with a comprehensive alternative to existing capitalist society by offering them a better and more just lifestyle than that provided by capitalism. This form of "ghetto socialism" posited that the unions, and their affiliated parties and cooperatives, provide the workers and their families with all their social, economic and political needs. ${ }^{12}$

Alber, “Govemment Responses", p. 152. In the United States, an early attempt to establish an unemployment fund was made by a New York printers' local in 1831 but the idea did not gain much support within the American labour movement.

See J. Clasen, Paying the Jobless (Aldershot, 1994), p. 52.

10 For a survey of the development of early UI programmes, see ILO, Unemployment Insurance Schemes (Geneva, 1955). For an overview of the differences between the policies of the labour movements in different national settings during this period, see D.E. Ashford, The Emergence of the Welfare State (Oxford, 1986), pp. 187-239.

1 While I.M. Rubinow, in his early study of trade union UI, Social Insurance (New York, 1965; 1st pub. 1913), regarded the funds as merely "a natural function of labour organizations" (p. 457), other observers have emphasized its appeal to new members. For example, in his study of the development of UI in inter-war Belgium, Vanthemsche ("Unemployment Insurance in Interwar Belgium", p. 361) notes that "the number of union members in Belgium increased markedly from around 610,000 to 907,000 in the short period between 1929 and 1938. There can be no doubt that this increase is explained by the flight of working people to the unemployment funds". The notion that UI could assist unions in dealing with the wage depressing effect of unemployed workers was expressed openly by the leadership of the German unions. In 1896, the German Trade Union Congress supported the extension of trade union unemployment funds because, among other reasons, it was assumed that they would improve the bargaining positions of the unions by reducing the wage depressing effect of a "reserve army" of workless people: see Clasen, Paying the Jobless, p. 52 and Alber, "Govemment Responses", p. 152. In Britain, too, prevention of wage depression was seen as a primary motivation for the introduction of out-of-work benefits by unions. This view was expressed forcefully in S. and B. Webb, Industrial Democracy (London, 1919), pp. 161-165.

12 For a discussion of the idea of labour movements establishing a substitute society for their members, see E.M. Kasselow, Trade Unions and Industrial Relations (New York, 1969), pp. 5-28. For an elaboration of the idea of the "ghetto approach" to socialism 
In practice, however, the various goals of union UI programmes were faced with a more complex reality, particularly during periods of mass unemployment. A major limitation of the union unemployment funds was that, at the best of times, these funds were limited in the scope of their membership. They provided protection only to those members of unions with UI programmes. These were usually the better-organized and more highly skilled segments of the working class, while the vast number of non-unionized and unskilled workers, or those belonging to unions which did not have unemployment programmes, were unprotected. Yet these were those workers most vulnerable to unemployment. ${ }^{13}$ A second problem was that when unemployment did affect workers covered by union UI, very rapidly the financial pressure on the funds became unbearable. Union unemployment funds were invariably based on a far too narrow membership so that when mass unemployment hit the sector in which the union members found employment, the payment of benefits to out-of-work members depleted the financial reserves of the funds within a short time, causing frequent cuts in the level of benefits to the unemployed and their families and threatening the unions with bankruptcy.

The financial difficulties involved in the running of union UI programmes and the limited coverage provided by them led to efforts by unions and their political affiliates to seek alternative public sources of income for the funds. The involvement of local and regional government in unemployment programmes began in reaction to the mass unemployment brought on by the depression of the early 1890s in many European nations. The inability of union schemes to provide adequate benefits and, more important, their failure to provide for non-unionized workers led economists to suggest adopting the Bismarkian notion of social insurance to this field. The first attempt to establish such a fund was undertaken in the Swiss canton of St Gallen in 1895. While the programme lasted only two years due to a growing deficit and public dissatisfaction, it paved the way to growing public involvement in UI. ${ }^{14}$

among European socialists, see G. Esping-Andersen, The Three Worlds of Welfare Capitalism (Cambridge, 1990), pp. 24-25.

is In Britain, according to Heclo's figures (Modern Social Politics, p. 68), 13 per cent of the labour force was covered by union unemployment funds during this period. Kiehel (Unemployment Insurance in Belgium. p. 86) notes that no more than 10 per cent of the industrial workers in Belgium were covered by union UI at this time. In most other countries, the coverage was even more limited. In Sweden, for example, only 4 per cent of the labour force was covered (Heclo, Modern Social Politics).

14 A detailed description of the Swiss efforts to establish municipal programmes and indeed a very early attempt at this in Basle (in 1789) can be found in T.G. Spates and G.S. Rabinovitch, Unemployment Insurance in Switzerland (New York, 1931), pp. 31-40. References to the St Gallen experiment can also be found in B.B. Gilbert, The Evolution of National Insurance in Great Britain (London, 1966), pp. 265-266. The St Gallen programme was compulsory. Two years prior to its adoption, the city of Beme established a voluntary unemployment fund. In later years, similar programmes were set up in Cologne (1896), Leipzig (1906) and in a number of Swiss and French cities. However, due to the 
In the wake of the failure of municipal funds, a new approach to UI based on cooperation between local or regional government and trade unions was adopted. First introduced in Ghent in Belgium, the idea was that grants be provided by the city to unemployed workers to supplement other provisions against unemployment. Because over half of the workers in the city were already union members and thus incorporated in the union unemployment funds, the unions provided a relatively simple means through which the programme could be implemented. Moreover, as the programme was intended to supplement trade union funds, it was assumed that the union (which provided three-quarters of the benefits) would prevent abuse of the system. Thus, while a municipal body was chosen to administer the fund, the trade unions were charged with implementation. The Ghent programme was initiated in 1901 and, by 1903, was enlarged to include nearby communes. ${ }^{15}$ Because it did not only help solve the financial weaknesses of the union funds but also attracted new members to the unions and stabilized union membership, the Ghent model gained enthusiastic union support. By 1913, 68 communes and 414 trade unions were cooperating in Ghent-type programmes in Belgium and similar systems were adopted in France, Germany, Switzerland, Italy, Holland, Norway, Denmark, Finland and Britain. ${ }^{16}$ Another form of municipal-trade union cooperation in the field of UI was introduced in Liège in 1909 and later on by a number of other cities and communes in Belgium. Under this system, subsidies were paid directly to the trade unions rather than to the unemployed themselves. The administration of unemployment funds was left almost entirely to the unions, the city requiring only that the unions provide it with a financial statement. ${ }^{17}$

Despite the popularity of the Ghent model and its apparent success, growing unemployment very rapidly required constant increases in municipal funding that severely taxed the local governments, led to changes in eligibility conditions and benefit levels and eventually to central government subsidies for the funds. ${ }^{18}$ In the pre-World War I period, France,

voluntary nature of most of these municipal programmes, they generally attracted unskilled workers, who were often unemployed. Moreover, the insured workers were generally the sole source of income for the funds. As a result, the funds rapidly accumulated deficits and were abandoned after a short period.

is For detailed descriptions of the workings of the Ghent model, see I.G. Gibbon, Unemployment Insurance (London, 1911), pp. 82-107; Kiehel, Unemployment Insurance in Belgium, pp. 88-92 and Vanthemsche, "Unemployment Insurance in Interwar Belgium", pp. 351-353.

16 See ILO, Unemployment Insurance Schemes, p. 15.

17 See Kiehel, Unemployment Insurance in Belgium, pp. 95-97.

"I In Ghent itself, the affiliated communes were required to provide additional subsidies to the unemployment fund during the 1908-1909 depression and during the years immediately prior to World War I. During this period various changes were incorporated in the programme, most of which increased communal control over the unions or tightened eligibility conditions, such as introducing a mandatory waiting period (ibid., pp, 90-92). 
Belgium, Norway, Denmark and Holland passed laws or adopted policies according to which union unemployment funds were liable for state subsidies. During the decade following the war, many other European countries adopted similar laws. ${ }^{19}$ In most countries, state subsidies for trade union UI programmes were strongly supported by the various wings of the labour movement, particularly: the unions, and their parliamentary representatives were actively involved initiating government support for the funds. ${ }^{20}$ There were, however, some notable exceptions to this support, particularly in France and Norway. ${ }^{21}$

The inter-war period was characterized by a trend towards greater government involvement in compensation for unemployment, often in the form of the adoption of compulsory state unemployment insurance laws, which replaced or complemented existing union funds or, where no union funds had existed beforehand, initiated institutionalized solutions to the problems of the unemployed. ${ }^{22}$ After the first such law was adopted in Britain in 1911, during the inter-war years ten other countries adopted UI. ${ }^{23}$ The impetus to this trend was the need to find effective solutions to the widespread unemployment that swept through America and Europe during the 1930 s' Great Depression. $^{24}$ In some instances social-democratic parties were responsible for the introduction of UI, however in many others, the issue of compulsory state-run UI was the subject of bitter

19 See Alber, “Government Responses", p. 153; ILO, Unemployment Insurance Schemes, pp. 15-26.

${ }_{20}$ The German social-democratic unions began calling for subsidies in the mid-1890s (see G.V. Rimlinger, Welfare Policy and Industrialization in Europe, America, and Russia (New York, 1971), p. 128). This approach also received the seal of approval of the Second International. At its 1904 congress in Amsterdam, a report by the German expert on social security, Molkenbuhr, urging that insurance against unemployment and other risks be instituted, be paid for out of taxes, and be administered by labour organizations, was approved by a majority of delegates: G.D.H. Cole, Socialist Thought (London, 1956), p. 57. The issue was also a major subject of debate at the 1910 Copenhagen congress. The final resolution included a call for "general obligatory insurance", but, until the adoption of this demand, the congress called for state subsidies for trade union unemployment funds that would "leave the trade union organizations in full autonomy" (quoted in Therbom, The Working Class and the Welfare State, p. 5). For a detailed study of the Swedish socialdemocrats in the parliamentary struggle to institute Ghent-style subsidies for trade union unemployment funds, see Heclo, Modern Social Politics, pp. 70-78, 92-105.

${ }^{21}$ See Ashford, The Emergence of the Welfare State, p. 218; Alber, "Government Responses", p. 153; and Gilson, Unemployment Insurance, pp. 165-166, 192-193.

22 In contrast to this trend, in a number of countries (among them Finland, Spain, Czechoslovakia, Switzerland and Sweden) laws supporting state subsidies for union funds were adopted in the inter-war period (ILO, Unemployment Insurance Schemes).

2J Italy (1919), Austria (1920), Soviet Union (1922), Poland (1924), Bulgaria (1925), Germany (1927), Yugoslavia (1927), United States (1935), South Africa (1937), Canada (1940): ibid.

${ }^{24}$ For a discussion focused on the reaction of govemments and the labour movement to the mass unemployment of the depression years, see J.A. Garraty, "Unemployment During the Great Depression", Labor History, 17 (1976), pp. 133-159. 
struggle within the labour movement both within the social-democratic parties themselves and, in particular, between the trade union and political wings of the movement. ${ }^{25}$ Trade unions tended to regard compulsory UI as a threat to their autonomous role in the labour market and a threat to their appeal to members. The political wing of the labour movement, by contrast, generally supported state UI because of its universalistic nature and the political advantages that this could provide to a party seeking majority support. ${ }^{26}$

In most cases, the ravages of the depression and its financial implications for the union unemployment funds forced the trade unions to abandon their previous opposition to state-run UI. Thus, we find that, from the mid-1930s onwards, trade unions reconciled themselves to the idea of compulsory state UI. The question that remained open to a certain degree was no longer whether compulsory UI should be adopted but rather what form this would take. In particular, how to deal with the issue of worker contribution to the programme and the degree of trade union participation in its administration. ${ }^{27}$ While most trade unions appear to have accepted purely state-run schemes with varying degrees of worker contribution to funding, others sought Ghent-style schemes which left the administration (though not the funding) in union hands. This was the case in most Scandi-

2s An extreme example of this was the American case, in which Samuel Gompers and the AFL leadership vehemently opposed state-run UI until the beginning of the 1930s, regarding it as a "utopian dream" and as an attempt by the govermment to control workers. Though Gompers himself was actively involved in a struggle for out-of-work funds while serving as a young labour activist in the Cigar Makers' Union during the early 1870s, by the second decade of the twentieth century, the American Federation of Labor, under his leadership, had adopted a strongly anti-state unemployment insurance policy. Despite pressure for a change in this policy both by political and social forces outside the AFL and within, the federation maintained its opposition to UI until the early 1930s. Only intense pressure by many of the major affiliated unions at the federation conventions in the first years of the 1930s convinced the AFL executive to change its position in 1932. For more on this process, see L.L. Lorwin, The American Federation of Labor (Washington, 1933), pp. 281-297 and Nelson, Unemployment Insurance. In Britain, too, the adoption of the 1911 law was supported by a majority of the parliamentary Labour party but rejected by large majorities in subsequent party conferences, see Marwick, "The Labour Party and the Welfare State", pp. 380-403. Also see K.D. Brown, Labour and Unemployment 19001914 (Newton Abbot, 1971), pp. 164-174 and P. Thane, "The Working Class and State 'Welfare' in Britain, 1880-1914", The Historical Journal, 27:4 (1984), pp. 87-90. In Belgium, also, similar struggles took place within the trade union movement, see Vanthemsche, "Unemployment Insurance in Interwar Belgium", p. 368-371.

${ }^{26}$ See Esping-Andersen, The Three IVorlds of Welfare Capitalism, for a discussion and quantitative examination of this claim.

${ }^{27}$ In the years of the Weimar Republic in Germany, these issues were the subject of major concern for the unions and their representatives in the SDP (Clasen, Paying the Jobless). These issues were also raised by the trade union federations in the United States and Canada during the debates that immediately preceded the adoption of state UI programmes (Rimlinger, Welfare Policy and Industrialization, p. 219 and Pal, State, Class, and Burcaucracy, pp. 62-65). 
navian countries, in which trade union control over the UI administration was perceived as a means of ensuring high union membership levels. ${ }^{28}$

In the case of the Israeli labour movement, the initial stages of the evolution of policy towards the unemployed were similar to those common in the European countries described here. However, unlike other labour movements, upon gaining state power after independence in 1948, the Israeli movement actually opposed the adoption of a state-administered UI programme and did nothing to encourage the emergence of union-based schemes. The remainder of the paper will attempt to explain why this was so.

\section{THE ISRAELI LABOUR MOVEMENT AND THE LABOUR MARKET IN PALESTINE}

The origins of the Israeli labour movement can be found primarily in the immigration of radical young Jews from Russia to Palestine in the early decades of the twentieth century. These immigrants sought to establish a Jewish state in Palestine based on the egalitarian ideas dominant in the Russian revolutionary movement. When Great Britain received a mandate to rule Palestine in the wake of World War I, it found a land comprising a majority of Arab inhabitants and a minority of Jews (11 per cent), most of them immigrants.

During the British Mandatory period, which lasted until the establishment of Israel in 1948, the country underwent a process of rapid modernization and economic growth. ${ }^{29}$ Buoyed by an influx of population, capital and technology, a significantly improved physical and administrative infrastructure, and enhanced links with Europe and other Middle Eastern countries, the country transformed from a predominantly agriculture-based rural society to one with a strong industrial base and a growing urban population. ${ }^{30}$ However, this period was also marked by an escalating con-

28 For a comparison of the different schemes and a discussion of the adoption of the Ghent system in Sweden, see B. Rothstein, "Labor-Market Institutions and Working-Class Strength", in Steinmo et al., Structuring Politics, pp. 33-56.

${ }^{29}$ Though it should be noted that this process had in fact begun in the decades prior to World War I due to growing trade links to, and immigration from, Europe: see G.G. Gilbar, "The Growing Economic Involvement of Palestine with the West, 1865-1914", in D. Kushner (ed.), Palestine in the Late Ottoman Period (Jerusalem, 1986), pp. 188-210.

${ }^{30}$ By 1945, the size of the urban and the rural populations was nearly equal $(872,090$ inhabitants in villages and 825,880 in towns and cities) as compared to an urban population of 264,317 and a rural population of 492,865 in 1922 . The number of industrial establishments grew from 1,236 in 1927 to 3,470 in 1942. Imports grew 533 per cent and exports 956 per cent in the period between 1922 and 1944; see S.A. Himadeh, Economic Organization of Palestine (Beirut, 1938), p. 221; Statistical Handbook of Middle Eastern Countries (Jerusalem, 1945), p. 3; Statistical Abstract of Palestine 1944-45 (Jerusalem, 1946), pp. 21 and 63. 
flict between the two major ethnic communities in Palestine, the Arabs and the Jews. Both developed virtually separate political, social and cultural institutions and struggled for dominance. This separation and differentiation also characterized, to a large degree, economic links between the two communities and their roles in the labour market, particularly following the violent civil unrest of the late $1930 \mathrm{~s}^{31}$

The Arab community in Palestine grew in size from 670,000 in 1920 to $1,200,000$ in 1948 . While it remained a predominantly rural population during the entire period, there was significant growth of the Arab urban sector, to approximately a third of the total in the late 1930s. Being a predominantly rural society, the Palestinian Arab occupational structure also remained mainly agriculturally-based. Though the 1930 s and, especially, the war years saw growth in the number of Arabs engaged in wage labour (reaching a third of the male labour force in 1945), the majority of Arabs still derived their living from agriculture throughout the Mandatory period. Due to the agricultural basis of society, the Arabs apparently did not undergo large-scale unemployment during the 1920s. It was only after significant numbers of Arabs (even though many still lived in villages) found their livelihood in wage labour, often on a seasonal basis, did unemployment begin to have relevance to many of them. While data remain scanty (due partly to the lack of an employment exchange that could provide adequate information), it appears that during the 1936-1939 recession and civil strife large numbers of Arabs were unable to find jobs. Another result of the structure of Arab society was the difficulties that were encountered by those who sought to establish representative trade unions. ${ }^{32}$

31 It is worth noting, however, that prior to the mid-1930s and, to a certain degree, during World War II and immediately afterwards, there were fields in which economic links and even trade union cooperation existed. For example, during the mid-1930s, 35 per cent of the employees in Jewish agriculture were Arabs as were 12 per cent of the workforce in construction and 25 per cent in transportation and ports (B. Kimmerling, Zionism and Economy (Cambridge, MA, 1982), p. 50). In addition, in a number of workplaces in which both Jews and Arabs were employed there were cases of joint worker committees and labour stnuggles: see Z. Lockman, Comrades and Enemies (Berkeley, 1996).

${ }^{32}$ For more on the nature of the Arab economy in Palestine, see Himadeh, Economic Organization of Palestine, pp. 213-300; D. Horowitz and R. Hinden, Economic Survey of Palestine (Tel Aviv, 1938), pp. 203-214; and R. Owen, "Economic Development in Mandatory Palestine: 1918-1948", in G.T. Abed (ed.). The Palestinian Economy (London, 1988), pp. 13-35. On the emerging Arab industrial labour force, see R. Taqqu, "Peasants into Workmen: Internal Labour Migration and the Arab Village Community under the Mandate", in J.S. Migdal (ed.), Palestinian Sociery and Politics (Princeton, 1980), pp. 261286. On the problematic issue of Arab unemployment see Colonial Office, Palestine and Transjordan for the Year 1938 (London, 1939), p. 132 and the comment in Bulletin of the Rescarch Institule of the Jewish Agency for Palestine, II, 3/4 (1938) pp. 42-43. Membership in Arab trade unions at the end of the Mandate was still small. The largest Palestinian Arab Workers' Society claimed 15,000 members and the smaller Federation of Arab Trade Unions claimed 1,500 members, the same as in the Histadrut-organized Palestine Labour League: see Statistical Abstract, p. 132 for statistics and S. Tamari, "Factionalism and 
During this period, the Jewish community, the "Yishuv", was characterized by nearly constant demographic growth due to continuous immigration, a high level of industrialization and agricultural development financed by an influx of funds from the world Jewish community and private investment, and the emergence of diverse political and social institutions. From a minority of 11 per cent in 1920, the number of Jews in Palestine reached 600,000 in 1948 , comprising a third of the country's population. The vast majority of the Jewish population was concentrated in a number of large cities and towns with only a quarter to be found in agricultural settlements and villages. Jewish employment statistics for the last years of the Mandate indicate that nearly 30 per cent were engaged in industry and only 13.2 per cent in agriculture. Fully 37 per cent of the national income of the Jewish economy was a result of manufacturing. While during much of the Mandatory period, immigration and economic growth created opportunities for full employment, there were a number of significant economic recessions which created large-scale unemployment among Jews. ${ }^{33}$

Though there was great variety of political views among the Jews in Palestine, the labour movement enjoyed political dominance from an early stage. ${ }^{34}$ This dominance was reflected in the power of the institutions established by this movement, among which the Histadrut, the General Federation of Labour, was of particular importance. The Histadrut was formed in 1920. It sought to unite various political parties that had emerged among the Jewish immigrants and to integrate the social and economic functions that they had been engaged in. While, initially, its efforts to recruit members were. only partially successful, by the end of the Mandatory period it could claim that 74 per cent of the Jewish workers were members. ${ }^{35}$ The structure of the Histadrut reflected the origins of its

Class Formation in Recent Palestinian History" in R. Owen (ed.), Studies in the Economic and Social History of Palestine in the Nineteenth and Twentieth Centuries (Basingstoke, 1986), pp. 177-202.

${ }^{33}$ On Jewish population and occupational distribution, see Statistical Handbook, pp. 3 and 5. For data on the economic structure of the Jewish community in Palestine, see R. Szereszewski, Essays on the Structure of the Jewish Economy in Palestine and Israel (Jerusalem, 1968).

${ }^{34}$ For introductions to the history of Zionism and the Jewish community in Mandatory Palestine, see D. Horowitz and M. Lissak, Origins of the Israeli Polity (Chicago, 1977) and W.Z. Laqueur, A History of Zionism (London, 1972).

${ }^{35}$ For data on Histadrut membership, see A. Gertz (ed.), Statistical Handbook of Jewish Palestine (Jerusalem, 1947), p. 290. For English language studies of the development of the Histadrut and the Jewish labour movement, see I. Avrech and D. Giladi (eds), Labour and Society in Israel (Tel Aviv, 1973); J. Glatt, The Historical Development of Histadrut (Ann Arbor, 1976); J. Kurland, Cooperative Palestine (New York, 1947); G. Muenzner, Jewish Labor Economy in Palestine (Jerusalem, 1943); W. Preuss, The Labour Movement in Israel (Jenusalem, 1965). For more critical studies of the Histadnut, see L.L. Grinberg. Split Corporatism in Israel (New York, 1991) and Shalev, Labour and the Political Economy in Israel. 
founders. From the beginning it was a very centralized organization with power being distributed according to the results of competition between party lists in regular elections. Membership was direct and, for the first decades of its existence, there were no national trade unions representing workers in specific occupations. While policy was decided upon in the central decision-making bodies, local activities were undertaken by workers' councils which were established in towns and cities. These councils also represented workers in labour disputes. Though the workers' councils were democratically elected by the Histadrut members in a specific locality, in practice the councils were funded and generally tightly controlled by the central body. As a trade union organization the Histadrut was actively involved in a struggle for worker rights (primarily those of Jews) in the workplace, but at the same time it also engaged in additional activities such as the establishment of economic enterprises, communal agricultural settlements (Kibbutzim and Moshavim), educational and social insurance institutions (initially health), a labour exchange and cultural activities.

Though this model of trade union activity is overtly similar to that adopted by European unions of the time which sought to establish substitute working-class societies, the motivation of the Histadrut was unique for a number of reasons. While the Histadrut did indeed seek to establish a more egalitarian society through these institutions, it was strongly motivated by the national aims of the Zionist movement, to which it affiliated. The Histadrut was perceived as a vehicle through which the goal of Jewish independence in Palestine could be achieved. Thus, the World Zionist Organization (WZO) directed much of the funds gathered from Jews the world over to the Histadrut and its activities. Given the reluctance of the Mandatory government to undertake costly activities in economic or social spheres, the Histadrut rapidly filled this void and served as a virtual "state-in-the-making". From its inception, the Histadrut served as a major power base for the dominant labour movement political party, Mapai, and it provided an avenue for political recruitment, enabling Mapai to gain early dominance within the Yishuv and the Zionist movement. ${ }^{36}$ The Histadrut was also very much engaged in a struggle for the role of Jewish workers in the labour market. Due to their inability to work for the low wages received by Arab workers, Jewish workers were often unable to compete with Arabs for work in agriculture and manufacturing. The Histadrut actively participated in Zionist attempts to convince Jewish employers to employ solely Jewish workers despite the additional costs involved. These efforts were only fully successful following the 1936 Arab Strike, which

${ }^{36}$ For studies focused on Mapai, see P. Medding, Mapai in lsracl (Cambridge, 1972) and Y. Shapiro, The Formative Years of the Israeli Labour Party (London, 1976). 
led to the almost complete separation of the economies of the two communities. ${ }^{37}$

UNEMPLOYMENT INSURANCE IN PRE-STATE PALESTINE

\section{Early Attempts to Deal with Unemployment}

Large-scale unemployment first reared its head a few short years after the establishment of the Histadrut. From the middle of 1922 and throughout 1923, a crisis in the building sector due to cuts in public expenditure and a lack of capital inflow into the country led to a rise in the number of unemployed Jewish workers, to approximately 12 per cent throughout the country. ${ }^{38}$ In the port of Jaffa, where many of the new Jewish immigrants were to be found, the situation was particularly bad. The Jaffa workers' council wamed of an imminent "catastrophe" due to the fact that 1,500 workers in the city lacked employment for months on end. In a letter sent to the Histadrut leadership, the entire council submitted its resignation complaining that it could "no longer control the situation". 39

The Histadrut leadership, in turn, sought to put pressure on the Zionist organization and the local Jewish authorities to create new places of employment in order to provide income for the unemployed, many of whom were reported not to have worked for five or six months and were close to starvation. ${ }^{40}$ In reaction to the growing unemployment, the Jaffa workers' council frantically sought additional places of work for its out-ofwork members and through its control of the labour exchange, sought to distribute the work that it had to as many job-seekers as possible. It offered employment to many of the unemployed, particularly to single men, in the Jewish agricultural settlements outside Jaffa. In addition, the Histadrut executive council asked all of its working members to donate one day's wage to the unemployed. The Jaffa workers' council sent a letter to its working members and asked them to donate between two and four work days each month to the unemployed, noting that an unemployed family of five could exist for a week off a single day's wage. ${ }^{41}$

37 This issue of Jewish labour in the Jewish economy is dealt with at length in A. Shapira, Hamavak Hanihzav: Avoda Ivrit, 1929-1939 (Tel Aviv, 1977) and in Kimmerling, Zionism and Economy.

38 See N. Halevi, Hahitpathut Hakalkalit shel Hayeshwv Hayeludi Beeretz Yisrael 19171948 (Jerusalem, 1979), pp. 16-18.

${ }^{39}$ See Moetzet Poalei Yafo, Din Veheshbon shel Moetzet Poalei Yafo (Jaffa, 1924), pp. $38-40$.

${ }^{40}$ See comments of labour leader David Remez at a meeting with the Zionist Executive in Jerusalem, 17 April 1923, p. 1, Central Zionist Archives.

${ }^{11}$ On the activities of the Histadrut during this period, see L. Kantor, Hazroa Hamiktzoit (Tel Aviv, 1966), pp. 151-152. On the activities of the Jaffa workers' council, see A. Milshtein, Keren Hoser Avoda 1933-194I (Tel Aviv, 1985), pp. 7-12. 
The duration of the 1922-1923 economic crisis was brief and an influx of immigrants during 1924 brought with it new economic growth and a dramatic drop in unemployment. As a result, most of the efforts to deal with the unemployed were ad hoc rather than the result of a planned organized effort. However, the lull in unemployment was short-lived. By mid1925, the economic atmosphere darkened once again. A drop in the number of immigrants and the fact that many of those who came arrived penniless, the decreasing value of the Polish currency (and, as a result, a decrease in the income source of many of the immigrants who came from Poland), and the over-extension of many of the investors in the construction field in Palestine all contributed to a very severe economic downturn that rapidly led to mass unemployment. At the height of the crisis, which lasted until the middle of 1928,35 per cent of the Jewish labour force was out of work. In the new city of Tel Aviv in which the largest concentration of Jewish workers was to be found, 40 per cent were unemployed. In the port city of Haifa, one of every two workers was jobless during 1927.42 The long periods of unemployment undergone by many workers and their lack of reserve resources led to a very sharp drop in living standards and worse. In Tel Aviv, there were reports of hundreds of families on the verge of starvation. In Haifa, families that were unable to pay their rent were forced into the streets. ${ }^{43}$ The economic conditions and lack of work also resulted in growing discontent. In Tel Aviv, demonstrations broke out and groups of workers attempted to march on the workers' council building. In Haifa, Histadrut officials in the labour exchange were often attacked by fnustrated job-seekers. Jewish immigration to Palestine dwindled while, at the same time, ten thousand Jews (of the 160,000 Jewish population at the time) left the country. Indeed, in 1927 the number of Jews emigrating from Palestine was significantly larger than the number arriving in the country. The leaders of the labour movement regarded the mass unemployment and its consequences, in particular emigration, as a threat to the very future of the Zionist project in Palestine. There were fears that the inability of the Jewish community to deal with the economic crisis would convince the British Mandatory authorities of the futility of Zionism and lead to an end to Jewish settlement in Palestine. These fears were indeed justified. The British High Commissioner, Lord Plumer, was

\footnotetext{
12 For more details on the economic aspects of the crisis, see D. Giladi, Hayeshuv Bctkufat Haaliya Hareviit (Jerusalem, 1968), pp. 180-197. Details of unemployment in Haifa during this period can be found in D. De Vries, Tnuat Hapoalim Behaifa (Tel Aviv, 1991), p. 333. ${ }^{43}$ For more on the privation of unemployed Jewish workers in Tel Aviv and in Haifa, see Moetzet Poalei Yafo, Din Veheshbon Mipeilut Moetzet Poalei Yafo (Jaffa, 1927), pp. 125142, and De Vries, Tnuat Hapoalim Behaifa, pp. 336-341. These descriptions were also confirmed by the Mandatory authorities who noted in December 1927 that "many of the people in Tel Aviv are very near starvation" and that "many of the Tel Aviv men are becoming physically unemployable" (quoled from letter from H.C. Plumer to Colonial Office, Public Records Office, CO 733 140/2).
} 
convinced that only mass emigration of Jews would lower the workforce size to a level feasible for the country's economic capacity. ${ }^{44}$

In its attempts to deal with the growing unemployment levels, the Histadrut initially adopted similar policies to those that prevailed during the previous bout of unemployment. Through its local labour exchanges, the Histadrut attempted to distribute work to as many workers as possible. Unemployed workers with families to support or those in particularly difficult financial straits were granted preferential treatment. At Histadrutowned enterprises, such as construction gangs, the federation sought to employ two or three workers at a single job. In other cases, it convinced employers to limit the working day or week in order to find employment for additional workers.

Another form of mutual aid was a system which enabled unemployed workers to substitute for employed workers at their job for a number of hours during the week and, by doing so, earn a minimal income. This system was first initiated by members of the baker's union in Jaffa in 1921 and, with the outbreak of mass unemployment in 1925, it was also adopted by printers and wall-painters. However, it appears that the small, tightlyregulated and highly solidaristic baker's union was the only union that managed to maintain this system of job substitution for any length of time. During 1925 the union distributed 200 workdays to fifteen unemployed bakers and, with the worsening of the crisis, the union decided that each of its married members would donate six nights a month to unemployed substitutes and that its single members would donate ten days a month. ${ }^{45}$

" For details on the levels of emigration, see M. Braslavski, Tnuat Hapolaim Haeretz Yisraelit, vol. 2 (Tel Aviv, 1956), p. 34. A resolution expressing the labour movement's view regarding the possible implications of the crisis was approved by the Histadnut general council in 1927. The council warned that the situation was liable to lead to the "collapse of the Zionist enterprise in Palestine" and to "the intervention of the government and a decision to force the Jews to leave the country", quoted in Kantoor, Hazroa Hamiktzoit, p. 160. Justification for these fears can be found in a confidential dispatch sent by Lord Plumer to the Colonial Office in London in December 1927 in which Plumer wrote that in order to deal with unemployment, alongside the dole and relief work, "there is only one practical remedy and that is to further by every possible means emigration from Palestine of the surplus Jewish population and for this the Palestine Govermment and the Zionist Executive must work in co-operation" (Public Records Office CO, 733/14, p. 4).

4s The Jaffa workers' council reported that it managed to create 44,400 workdays during 1925 through these efforts (Moetzet Poalei Yafo, Din Veheshbon, p. 132). With regard to the bakers' union, the system of job substitution was apparently common among bakers in Poland, from which the founders of the Palestine union came. Despite the immense difficulties involved in maintaining this system over time, the local bakers' unions in Tel Aviv, Haifa, Jerusalem and other cities managed to implement job substitution among members until the end of the 1930s. For details of this system, see "Ezra Lemehousarei Haavoda bein Poalei Haafia", Davar, 5 April 1931, p. 3; Moetzet Poalei Yenushalaim, Din Veheshbon 1929-1932 (Jerusalem, 1932), pp. 54-56; Moetzet Poalei Haifa, Hahisıadrut Behaifa (Haifa, 1939), pp. 147-150; Agudat Poalei Haafia Tel Aviv-Yafo, Skira Mipeulot Vaad Haguda Mertz 1943-August 1944 (Tel Aviv, 1944), pp. 3-4. 
In addition to these steps, employed workers were required to contribute part of their salary to efforts to create iobs for the unemployed or to provide income support for them. In Tel Aviv, employed workers were asked to contribute the equivalent of between two and four days a month. In 1927, the Histadrut council decided that single employed members would be required to contribute the equivalent of a full day's work every month and married members half a day's work. However, being a voluntary organization the Histadrut was unable to enforce this demand and it was successful primarily among workers employed directly by the Histadrut or other public institutions. ${ }^{46}$

Apart from its efforts to distribute existing jobs to as many workers as possible, the Histadrut sought to create additional places of employment for its unemployed members. Utilizing funds that it managed to raise from its own members, the Histadrut undertook a number of projects of its own. However, given the partial response to its internal fund-raising drive, the scope of these efforts was limited. As a result, from 1925 onwards it pressured the government, the WZO executive and the local municipalities to initiate public work projects. The response was, however, disappointing. Initially, the government tumed a blind eye to the situation and the response of the Zionist organization and the local authorities was limited and slow in coming both because of a lack in resources and their doubts as to the severity of the crisis. In a tense meeting between the Histadrut leadership and the heads of the Zionist organization in October 1926, well into the crisis, the labour movement representatives complained bitterly that of the 3,500 unemployed workers in Tel Aviv only 200 had managed to find employment in projects funded by the WZO. Colonel Kisch, who chaired the WZO executive, estimated that the crisis would abate within a few months and he was therefore unwilling to invest too much of the organization's limited funds in large-scale public works projects. ${ }^{47}$

In mid-1926 it became obvious to all the parties involved that the internal efforts of the Histadrut and the limited public works initiatives were unlikely to provide for the basic needs of the majority of unemployed workers. The response adopted by the WZO was the provision of direct assistance to the unemployed workers. From June 1926 the organization began providing, through the workers' councils, assistance to the unemployed. The assistance programme was aimed at providing a minimal income to workers unemployed for over two months. It was conditional upon registration at the labour exchange three times a week and an interview with a committee appointed by the labour exchange management.

${ }^{4}$ See Moetzet Poalei Yafo, Din Veheshbon, p. 132; Kantoor, Hazroa Hamiktzoit, p. 162; De Vries, Tnuat Hapoalim, p. 353.

4 Sce minutes of the WZO executive in Palestine, 20 October 1926, pp. 1-4, Central Zionist Archives. 
By mid-1927, over 6,000 unemployed workers were receiving monthly assistance. ${ }^{48}$

The assistance level, its regularity and its effect upon the morale of workers were issues of constant tension between the labour movement leadership and the WZO executive during this period. Workers' council officials, who were charged with distributing the aid, were frequently unable to provide assistance to all the unemployed and the lines for assistance were often the site of violence between the out-of-work. Moreover, as the number of unemployed grew and the crisis lengthened, the WZO sought to cut the assistance level. These attempts led to frequent and outspoken protests by the workers' councils and eventually to threats to wash their hands of the entire project, thereby directing the fury of the unemployed towards the WZO itself. ${ }^{49}$ More problematic from the Histadrut's point of view was the impact upon the morale of its members. Ever since its establishment, the Jewish labour movement had stressed the importance of labour. It regarded labour, and particularly physical labour, as a moral act with a collective value far beyond its instrumental function. Labour was perceived as something that would ennoble people, restore the dignity of the Jewish people and enhance the links between the workers in Palestine and the land itself. As such, the fact that thousands of the new immigrants could not find work and were dependent upon handouts to survive appalled the labour movement leadership. ${ }^{50}$ The refusal of the WZO to invest in large-scale public work projects rather than in assistance alone, despite constant Histadrut pressure, infuriated the labour movement leadership. In a speech to the Histadrut council in 1927, the secretarygeneral David Ben Gurion attacked the WZO for its refusal to provide work for the unemployed and he called for severing the links between the

4 See Schindler, "Unemployment Assistance", pp. 356-361. For data on the number of assistance recipients, see Mispar Mekablei Siua Behodashim Yuly, August-September 1927. Central Zionist Archives, S9 1871b.

${ }^{49}$ See, for example, a letter sent by the Jaffa workers' council to the WZO executive in March 1927 which demanded a raise in the assistance level: "Hundreds and thousands of our members are degenerating. Over time everyone needs to fix his clothes or buy new shoes, and to pay the rent, even it is only a few prutot. The existing assistance level, which is not sufficient for even limited needs, obviously does not allow our members to take care of these additional elementary needs": Central Zionist Archives, S9 1789b/2. See also De Vries, Tnuat Hapoalim, pp. 353-361. For the view of the Zionist Executive leadership of these efforts see F.H. Kisch, Palestine Diary (London, 1938), pp. 229-230.

so A.D. Gordon, one of the ideologues of the labour movement, wrote: "[...] from now on our primary ideal should be work [. . . ] Labour should take its place as the focus of our aspirations, it should serve as the foundation of our building. If only we can discover the idea of labour, we can be healed from our affliction, and bridge the gap that has separated us from nature": see A.D. Gordon, The Nation and Labour (Jerusalem, 1952), p. 137. See B.Z. Shapiro, Social Welfare Policy in Israel: An Ideological Analysis (Jerusalem, 1972) for a discussion of this ideological approach to work. This period has been termed "one of the darkest and depressing periods in the history of the labour movement in Palestine": see D. Even-Shoshan, Toldot Tnuat Hapoalim Beeretz Yisrael (Tel Aviv, 1966), p. 131. 
Histadrut and the WZO. While the proposal was rejected by a small majority, it served clear notice to the WZO of the labour movement's frustration and anger. ${ }^{\text {s! }}$

The Histadrut pressure and the spiralling cost of assistance eventually led to a reappraisal of the WZO position. The initiation of govemment public work projects, additional donations from Diaspora Jews and the use of funds earmarked for the next year's budget enabled the WZO to embark on a number of large-scale projects that did indeed help provide work for many of the unemployed. ${ }^{32} \mathrm{~A}$ gradual improvement in the economic situation allowed the WZO to halt its distribution of assistance entirely by March 1928..$^{33}$

The end of mass unemployment, and with it the hated assistance programme, also brought to an end, temporarily at least, the Histadrut's efforts to deal with unemployment. However, the lessons of this period were not forgotten. During this proto-union UI period, the Histadrut had attempted to adopt a variety of methods for dealing with unemployment. Yet, within a short period of time, the federation had become totally dependent upon the goodwill of the WZO executive for assistance. Not only had it little control over the nature of the programme but it had had the unenviable task of actually facing the unemployed, handing out the meagre support and explaining why there were no job offers. The Histadrut leadership and officials had also witnessed the demoralizing effects of unemployment on the rank and file of the organization and seen the results - growing emigration and a weakening of internal solidarity. Not surprisingly, the leaders of the labour movement decided to adopt an alternative strategy and to prepare for any future outbreaks of mass unemployment ahead of time. A union unemployment insurance fund was one of the mechanisms that they sought to develop.

\section{The Establishment of the Unemployment Fund}

The idea of a union unemployment insuranre programme was initially raised within the Histadrut in the early $i=20$ s. In 1921 attempts were made to establish a loan fund for Histadrut members in Jaffa, yet they came to naught. ${ }^{34}$ Specific proposals to establish a fund for the unemployed were raised for the first time at a Histadrut council in 1923. While

s1 See D. Ben Gurion, "Lemilhama Behoser Avodah", Kontras (1927), pp. 7-14.

s2 On efforts by the WZO to gain government support for relief work rather than its assistance programme, see Memorandum submitted to His Excellency the High Commissioner by the Palestine Zionist Executive (22 February 1927): Public Records Office, CO 733/ 140/2. For details of the activities of the WZO in the employment sphere, see Report of the Executive of the Zionist Organization (submitted to the 16th Zionist Congress, 28 July7 August 1929), pp. 193-200.

s3 Sec Giladi, Hayeshow Betkufat, p. 197.

s4 See Milshtein, Keren Hoser Avoda, pp. 7-8. 
some members of the executive bureau called for the implementation of the decision to establish the fund during October of that year, the leadership preferred to postpone the decision and to concentrate on the establishment of economic enterprises. ${ }^{55}$ In fact, it was only in the wake of the unemployment crisis of 1926-1928 that the idea resurfaced.

A proposal to establish a union UI fund was raised at a Histadrut council meeting that was convened at the beginning of January 1929. The proposal was approved and the council called on the executive bureau to draw up proposals for unemployment and injury insurance. ${ }^{56}$ By the end of the month, a small committee was formed to investigate the issue. Utilizing their knowledge of the workings of union UI programmes in other countries, and in particular the British model, the committee members drew up a detailed proposal for a Histadrut UI fund. In its proposal the committee recommended that UI be compulsory for all members of the Histadrut. Funding for the programme was supposed to come equally from the government, employees and workers. Unemployed workers who had contributed to the fund for a minimum of 25 weeks would be eligible for compensation from the eighth day of unemployment for a maximum of 25 weeks. Eligibility for the compensation was dependent upon the worker's willingness to accept any "normal" job offer. ${ }^{57}$ The committee's proposal, along with two additional proposals (one of which was drawn up by the head of the Haifa workers' council), was finally presented to the Histadrut council in March 1931. It decided to form a committee comprising representatives of various sectors to discuss the different proposals and present its recommendations to the council. ${ }^{38}$

While the various Histadrut committees deliberated over the structure of the UI fund, a number of local initiatives to establish joint companyworker UI funds were under way. These initiatives were concentrated in the rapidly developing citrus-growing sector, one of Palestine's important agricultural sectors. The need to establish such funds in the citrus industry arose due to the fact that work in the groves was concentrated during eight months a year while during the remaining four months there was little or no work for the pickers. The goal of the fund was to provide an income for the pickers during this period of involuntary unemployment. The first such programme, and indeed the first unemployment insurance fund to be established in Palestine, was part of a work agreement signed in 1930 between the representatives of an American owner of the Gan Haim

ss See minutes of the executive bureau (va'ad hapoel) of the Histadrut, 4 October 1923 and 15 October 1923, pp. 218-219 and 228-229. A similar proposal was also raised during a Histadrut council in July 1926 but it had no impact.

${ }^{36}$ See minutes of the Histadrut council, 7-10 January 1929, pp. 33 and 70.

${ }^{37}$ See minutes of the committee for proposals for an unemployment insurance fund, 21 January 1929 and n.d, Labour Archives, IV-231-1.

se See Y. Kanevsky, Habituah Hosoziali Beretz Yisrael (Tel Aviv, 1942), p. 76. 
orange grove, the pickers' workers committee and the Histadrut. A year later another such fund was established in a second grove. ${ }^{59}$

The committee established by the Histadrut council to study the UI proposals accepted the principal elements of the earlier committee. It recommended that membership in the UI fund be obligatory for members of the Histadrut and that other workers would be allowed to join under certain circumstances. Assistance would take the form of either work, money or a combination of the two. The level of assistance would vary according to the marital status of the unemployed worker and the size of his or her family. The proposal included eligibility conditions very similar to those in the previous proposal. The major source of disagreement in the committee and in the deliberations of the various Histadrut institutions that discussed the issue was the question of whether to establish a single centralized fund or to create a federation of local funds linked to a central fund. While a minority in the committee advocated the establishment of a single fund for all the members of the Histadrut, arguing that separate local funds would create differences between Histadrut members in different locations and occupations and that the local funds would be unwilling to devote resources to the unemployed in other sectors, the majority supported the idea of establishing local funds and requiring them to devote a proportion of their resources to a central fund. ${ }^{60}$ During a period in which 38 per cent of the Histadrut membership was to be found in rural settlements and the country was in the midst of an economic boom, there was a very real fear that attempts to force members to pay additional dues to an unemployment fund would ferment opposition and even lead to splits in the Histadrut. ${ }^{61}$

The economic growth and lack of unemployment, a reluctance of the Histadrut leadership to become involved in a potentially expensive social insurance programme and the continuing debate over the structure of the

s9 See a report in the Haaretz newspaper, 1 September 1930 and the minutes of a meeting between the Gan Haim owner's representative and the pickers, 22 August 1932, Labour Archives, IV-235-3-43. On the second grove, see a letter sent by the pickers to the Histadrut's agricultural deparment, 22 July 1931, asking for advice on whether to demand the establishment of a UI fund, Labour Archives, IV-235-3-147 and a report in the Davar newspaper (2 February 1932) reporting on the existence of the fund. The funds were based on joint worker and employer contributions (4 per cent of wages by both sides). The funds existed for a number of years, but most of the money accumulated was not required. As a result, they were eventually converted to loan funds that enabled the pickers to establish agricultural settlements and buy land in the vicinity of the groves.

${ }^{60}$ See minutes of the unemployment insurance committee, Labour Archives, IV-208-333a. st The data on the distribution of Histadrut membership is based on the Histadrut statistical publication, Sikumim, 3 (1931), p. 3. Ben Gurion was particularly apprehensive regarding the implications of the fund upon membership. Upon hearing of the committee's proposals, he suggested that membership be both local and voluntary: see Ben Gurion's personal diary, 25 March 1932, p. 78, The Ben Gurion Archives. 
fund led to delays in reaching a decision to establish the UI fund. The committee proposal (which included the minority position on the fund structure) was debated at a Histadrut council meeting held in April 1932, but it was only at the following council meeting in November that a final decision to establish the fund was taken.

While the proposal eventually adopted was generally along the lines of the original plan, it did include a number of significant changes. First, a majority of the council members preferred a single fund, opting to adhere to the dominant centralist ethos of the Histadrut rather than the more pragmatic proposal to create a decentralized system of local funds. Second, in order to limit the potentially negative implications of this decision upon Histadrut membership, it was decided that participation in the fund would be compulsory but members who failed to pay their dues in the fund would not be forced to leave the federation. Third, in keeping with its approach to labour, the leadership stressed that the primary solution to unemployment was work and that only if no work could be found or created would assistance be given in the form of money. Fourth, it was emphasized that the fund was not a true unemployment insurance programme, in the accepted sense of the term, but rather a form of mutual aid and that it would not be able to deal with mass unemployment. This waming reflected the realization by the leadership that, despite formal calls for government and employer participation in funding, it would be the Histadrut membership who would bear most of the financial burden. ${ }^{62}$ On the basis of these principles, the council decided to begin collecting dues, varying between a quarter and 1 per cent of members' wages, from January 1933 onwards. The council also decided that the fund would begin operation only after a sum of 5,000 Palestine pounds was accumulated. ${ }^{63}$

The first three years of the existence of the unemployment fund were devoted primarily to fund-raising activities. With the economy growing rapidly, immigration continuing and unemployment virtually non-existent, there were no expenses apart from minimal operating costs. From early on, however, the fears as to the readiness of various sectors to contribute to the fund proved correct. The government ignored the fund and, to a large degree, so did employers (apart from those belonging to the Histadrut). Among the rank and file, the reaction to the calls for dues was also very lukewarm. During the initial months of the fund-raising efforts only a third of the urban members paid their dues. Moreover, the urban workers' councils, which were charged with collecting dues, tended to delay the forwarding of the funds preferring to finance local activities. However, while the urban workers' councils did eventually provide the

62 See the speech by M. Namirovsky (Namir) and the debate that followed at the Histadrut council. April 1926, pp. 1-59. For an analysis of this debate see Rosenthal, "Hoser Avodah", pp. 57-63.

63 For more details see Kanevski, Habituah Hasoziali, pp. 76-77. The value of a Palestine pound was equivalent to that of British pound. 
fund with a source of income, the situation among rural members of the Histadrut was far worse. Despite the fact that members of the communal agricultural settlements were required to pay a minimal amount to the fund, the vast majority failed to participate in the fund drive. By the end of the first year of existence of the fund, 95 per cent of the members of this sector had yet to contribute anything to the fund. Thus, although the fund managed to accumulate a sum of 37,000 Palestine pounds during this period, 70 per cent came from urban members of the Histadrut, 13 per cent came from the rural membership, and the remainder from donations, employers and interest. ${ }^{64}$

\section{Depression, Unemployment and Public Subsidies for the Fund}

After more than a half decade of a large influx of Jewish immigrants and constant economic growth (no less than 7 per cent per annum), from the middle of 1935 onwards there began an economic downturn that, by mid1936, turned into a full-fledged depression lasting into 1940. Difficulties arising from the need to absorb a large number of financially weak immigrants, poor crops and over-investment in citrus groves were aggravated by an Arab general strike that began in 1936 and led to continuous civil conflict for the next three years. ${ }^{\text {sS }}$ The economic crisis rapidly led to growing unemployment. For the first time, thousands of seasonal Arab wage labourers, dependent upon wages paid by Jewish employers or Arab manufacturers in the towns and villages, were affected. ${ }^{60}$ Despite the fact that Jews replaced Arabs in many jobs left by them due to the strike, by 1939 8 per cent of the Jewish workforce was unemployed. Among members of the Histadrut, the situation was far worse. In the 1935-1936 period, 1012 per cent were out of work and in 1940 this level climbed to a high of 16 per cent. Unemployment was especially severe in the construction, small-scale manufacturing and agricultural sectors. As in the previous crises, the urban workers and particularly those in Tel Aviv suffered most.

4 For details of the activities of the unemployment fund during this period, see Y. Kanevsky, Kerern Hoser Avoda (Tel Aviv, 1933) and Sikum Peulot Keren Hoser Avoda, 15 July 1936, Labour Archives, IV-231-10. See also letters sent from the fund administrator, Yitzhak Finkelstein, to the Histadrut executive bureau dated 16 March 1933 (Labour Archives, IV-208-1-637) and a letter sent to the agricultural settlements by Finkelstein dated 28 August 1933 (Labour Archives, IV-231-3). For a personal account of the activities during this period see the autobiography by Y. Eylam (Finkelstein), Benetivei Maase (Tel Aviv, 1974), pp. 12-17. See also the account of this period in the biography of David Remez, the second secretary-general of the Histadrut (1935-1945), in S. Erez, Tkufa Ahat (Tel Aviv, 1967), pp. 176-186.

os See Halevi, Hahitpathut Hakalkalit, pp. 34-36 and N.T. Gross and J. Metzer, "Palestine in World War II: Some Economic Aspects", in G.T. Mills and H. Rockoff (eds), The Sinews of War (Ames, 1993), pp. 59-82.

${ }^{6}$ R.L. Taqqu, "Arab Labor in Mandatory Palestine 1920-1948" (Ph.D. dissertation, Columbia University, 1977), p. 162. 
Long-term unemployment caused severe hardship mainly for the families of unskilled new immigrants or those employed in the construction industry. The cases in which workers unemployed for months on end complained of an inability to feed and clothe their families or pay their rent were numerous during the height of the depression. ${ }^{67}$

During this period of large-scale unemployment, the unemployment fund served as a significant source of both direct financial assistance. for unemployed members of the Histadrut and also as a major financial instrument through which additional places of employment were created. Jobcreation activities were undertaken through a number of joint companies and funds established together with the Jewish Agency (which directed the activities of the Zionist movement in Palestine from the mid-1930s onwards). The most prominent of these, a joint stock company called Bitzur formed by the fund and the Jewish Agency in February 1936, created over 8,000 jobs in construction and public work projects over the next five years. Funds were also directed to creating jobs in the agricultural sector, the arts and the fishing industry and significant sums were provided for the construction of housing for workers. ${ }^{68}$ In addition, as the unemployment crisis continued, the fund devoted a growing proportion of its resources to direct assistance to the unemployed. Over 25,000 worker families received direct financial assistance from the fund during this period. At the same time, the unemployment fund participated in the establishment of soup kitchens, discount stores, the provision of free milk to schoolchildren, and the funding of health insurance for the unemployed. ${ }^{69}$

To a large degree, the depression and the subsequent rise in unemployment caught the Histadrut and the unemployment fund off guard. Clearly, the acute crisis that began a few short years after the establishment of the fund created very serious problems and dilemmas for the labour movement leadership. One of the most difficult of these related to the nature of the activities undertaken by the unemployment fund. Motivated by their

${ }^{67}$ For a discussion of unemployment during this period, see Grinberg, Split Corporatism, p. 44. For details of unemployment among Histadrut members, see W. Preuss, "Tnuat Haavtala Beshnot 1936-1940", in Netel Mirazon (Tel Aviv, 1941), pp. 39-49. For personal accounts of the hardship faced by working-class families in Tel Aviv, see letters sent to the workers' council seeking work and assistance, such as the following sent by Meir Epshtein in December 1937: "[...] We are penniless. We are being evicted from our room and have nowhere to go. I haven't paid rent for five months. The shopkeepers come daily and demand our debts that are now 16 pounds. What must I do ? My son is hungry and we have no bread at home. He will stop going to school because his shoes are tom and I cannot buy him new ones. He suffers from a heart ailment and he requires medication frequently. Since August 1936 I have worked less than four months. My situation is desperate and $I$ ask you: visit us and see how bad our situation is. Save a family from starvation" (Labour Archives, 1V-250-72-1-358).

as For a detailed review of the activities of the unemployment fund during this period, see Kanev, Habituah Hasoziali, pp. 83-92.

${ }^{6}$ Information on these activities can be found in a report in the fund's files in the Labour Archives, IV-208-1-2057, and in Kanev, Habituah Hasoziali, pp. 93-103. 
adherence to a moralistic view of labour and haunted by memories of the lines of workers seeking direct assistance during the 1925-1928 crisis, the Histadrut leadership sought to create jobs for the unemployed rather than hand out aid. Not surprisingly, then, the establishment of the Bitzur company was one of the first steps of the unemployment fund during the crisis. However, it rapidly became clear that job-creating activities would not provide the short-term needs of unemployed workers nor would they furnish jobs for a majority of the out of work. Thus, the proportion of the fund's resources devoted to direct aid grew rapidly from a low of 12 per cent in 1936 to a high of 66 per cent in 1940. In order to limit the "negative" implications of direct assistance upon the unemployed, the aid was formally defined not as a grant but rather as an interest-free loan that the unemployed worker was expected to pay back after returning to work. While quite significant efforts were made by the fund and local workers' council representatives to recoup the loans, the results were generally very poor. ${ }^{70}$

Major efforts were also made to encourage the unemployed to return to the workforce as quickly as possible. The efforts to limit dismotivation for work took the form of stringent discretionary eligibility conditions, a very low level of benefits, and active attempts to identify "scroungers". Due to the early onset of the depression and its emphasis upon its jobcreating function, the unemployment fund failed to create a bureaucratic structure through which to administer the distribution of direct assistance. The solution to this problem was found in the form of Mishan, a mutual assistance organization established by members of the Histadrut in Tel Aviv in 1931 with the aim of assisting Histadrut members in need. Instead of providing assistance directly to the unemployed, the unemployment fund channelled resources to local Mishan chapters or to workers' councils, who then distributed the aid to the unemployed. It rapidly became clear that the elaborate eligibility conditions adopted by the unemployment fund did not apply to aid distributed by Mishan. Not being a social insurance institution, Mishan did not require a qualification period from applicants for aid. At the same time, it was not bound by any requirements regarding eligibility conditions or the rights of the insured. As a result, the local Mishan chapters had almost total discretion as to the distribution

\footnotetext{
70 The figures on the distribution of the unemployment fund's resources are taken from ibid., p. 107. With regard to the return of loans, see Mishan Jerusalem. Din Velicshbon Mipeulot Haaguda MeApril 1936 - August 1937 (Jenusalem, 1937). Kanev reports that the percentages varied from a high of nearly 30 per cent in Jenusalem and rural towns to a low of 8 per cent in Tel Aviv and 6.6 per cent in Haifa (p. 95). A report sent to the Jewish Agency in 1942 found that 13 per cent of the money distributed as loans to individuals during the 1935-1941 period was actually paid back: see Central Zionist Archives, S9 1077. This report followed an agreement signed by representatives of the unemployment fund and the Jewish Agency in July 1941 to make a joint concentrated effort to recoup the loans and divide the sum recovered between them (Central Zionist Archives, S9 1069).
} 
of aid. Despite pressure from the Histadrut, the left-wing opposition and local social services, Mishan managed to refrain from drawing up a constitution and set of eligibility conditions during the entire period. The criteria for granting aid varied from place to place. Generally, in order to apply for assistance the unemployed had to receive the approval of the secretary of their local union that they had been out of work for all but 4-6 days during an entire month and that they had actively sought work by. appearing at the labour exchange daily. They then had to apply to the Mishan committee which decided which of the unemployed most urgently required assistance and how the funds were to be distributed. Finally, the unemployed had to submit a new application for assistance every month. ${ }^{71}$ Aside from the eligibility conditions, the programme tended to deter applicants because of the extremely low level of benefits. The benefits paid were the equivalent of merely 15 per cent of the average monthly expenditure. An unskilled labourer in the construction trade was able to earn a sum equal to the benefit granted a family of four during five days of work. ${ }^{72}$ Despite the discretionary nature of the distribution of assistance and the low levels of benefits, the Mishan administration sought additional means to deter "scroungers" among aid recipients. In an attempt to thresh out the undeserving, social workers paid visits to the recipients and checked on their living standard and sources of income. ${ }^{73}$

Another issue of concern regarding the activities of the unemployment fund was the exorbitant cost of the effort. Between 1936 and 1941, nearly 700,000 Palestine pounds was spent on these activities. Very early on, the Histadrut leadership realized that the sums accumulated by the fund prior to the outbreak of unemployment would not suffice. The Histadrut attempted to raise funds for the activities of the unemployment fund both through the regular dues collected from its members and by way of a series of highly publicized fund-raising drives, during which employed members were asked to contribute additional money to the efforts to assist the unemployed. In addition, it sought the support of public institutions. While the Mandatory government did not engage in efforts to alleviate

${ }^{71}$ For information on Mishan, see Moetzet Paolei Tel Aviv, Mishan (Tel Aviv, 1937). For descriptions of the eligibility conditions for loan applicants, see a report on the activities of Mishan in Tel Aviv between 1 October 1939 and 1 April 1940 (Labour Archives, IV251-3), reports on the activities of Mishan in Jerusalem (Labour Archives, IV-208-2158) and Rehovot submitted to the Jewish Agency (Central Zionist Archives, S9 1077), and a letter sent to the Jewish Agency (dated 24 April 1938) from the secretary of the workers' council in Tel Aviv (Central Zionist Archives, S9 1078a).

72 The monthly benefits granted to a family of four were 1.600 PP (report on Mishan activities in Tel Aviv, 1 October 1939-1 April 1940, Labour Archives, IV-251-3). The average monthly expenditure of a family of four in 1939 was $10.653 \mathrm{PP}$ and the daily wage of an unskilled labourer in the construction trade was 0.315 PP (Gertz, Statistical Handbook of Jewish Palestine, pp. 298 and 318.

${ }^{3}$ See report by social workers to the Mishan offices in Tel Aviv dated 12 January 1941 (Labour Archives, IV-251-9). 
unemployment until a late stage in the crisis, the Zionist movement and, to a certain degree, Jewish local authorities (in particular, the Tel Aviv municipality) were ready to subsidize the union unemployment fund. These subsidies grew from a very modest subsidy of 500 Palestine pounds in the first half of 1936 to one that comprised 45.6 per cent of the unemployment fund's budget in $1939 .{ }^{74}$ In addition, public funds subsidized directly Mishan activities on a local level and the unemployment funds established by religious, ethnic and political bodies other than the Histadrut. At the height of the crisis, the Jewish Agency devoted a tenth of its entire budget to direct assistance to the unemployed. ${ }^{75}$ The administration of the subsidies was similar to the Liège system adopted in Belgium. The Agency's labour department generally provided monthly subsidies on the basis of reports submitted by the unemployment fund regarding the number of benefit recipients in each locality. In comparison to the strained relations between the Histadrut and the Zionist organization during the previous unemployment crisis, the relations between the Jewish Agency and the Histadrut were much better during this period (due to the fact that Mapai now controlled both institutions and that many of the former leaders of the Histadrut, such as Ben Gurion, were now the dominant figures in the Jewish Agency). However, the degree of public support for the unemployment fund was the result of a continuous and, at times, difficult negotiating process between the two. The Jewish Agency preferred to devote its resources to constructive efforts in Palestine and to funding Jewish immigration rather than relief to the unemployed. In addition, it was under pressure to assist unemployed workers and professionals who were not members of the Histadrut. ${ }^{76}$ Despite the internal fund-raising activities and the subsidies provided by public sources, the unemployment fund was forced to loan large sums from commercial banks in order to finance its activities. These debts were the most prominent issue of discussion at the meetings of the fund's board of directors and were a subject of heated exchanges between the fund and Mishan, particularly following decisions by the unemployment fund to delay or cut the transfer of funds to Mishan. ${ }^{77}$

In addition to the perceived negative effect of assistance and the enormous economic burden that it entailed, the labour movement leadership

74 On the modest beginnings of the Jewish Agency's subsidies, see letter to E. Kaplan from Y. Rabinovitz, 24 July 1936 (Central Zionist Archives, S9 1078). On the total public subsidies to the fund, see Kanev, Habituah Hasoziali, pp. 104-108.

${ }^{73}$ See Reports of the Executives of the Zionist Organization and of the Jewish Agency for Palestine (submitted to the 22nd Zionist Congress, December 1946), Table 38.

${ }^{76}$ See minutes of the WZO executive, 6 November 1938, Central Zionist Archives.

7 See minutes of the unemployment fund board of directors, 30 May 1938, 24 September 1939, 4 December 1939 (Labour Archives, IV-208-1) and letter sent by the Mishan board of directors to the Histadrut threatening to resign if funds were not transferred, 14 March 1940 (Labour Archives, IV-208-1-2187). 
was faced with severe internal instability during this period. The low levels of benefits, the leadership's apparent inability to end the crisis, claims of discrimination in labour exchanges and Mishan committees against the unemployed who were not long-time loyal Mapai members, and growing income gaps between the unemployed and employed members of the Histadrut led to incessant political unrest among low-income and unemployed Histadrut members. The long-term unemployed in Tel Aviv, in particular, were receptive to left-wing criticism of the Histadrut leadership and they were instrumental in bringing about the formation of a powerful opposition faction within Mapai. ${ }^{78}$ At the same time, and perhaps even more worrisome, was the sense that the crisis had severely undermined solidarity within the Histadrut. As the crisis continued unabated and demands for contributions to the unemployment fund grew, so did dissatisfaction among higher-income employed members of the federation. By the end of 1939 , protests against the internal taxes were heard at the Histadrut council meetings and in the labour movement press. In a piece published in the influential journal, Hapoel Hatzair, Y. Horin attacked those calling for higher taxes on high-income working members of the Histadrut, noting that:

the difficult situation [...] is having a negative effect not only in the economic sphere - but is also causing worrying signs within the camp in the social sphere [...] We can observe a growing tendency that seeks, perhaps unconsciously, to put the blame for the current hardship and the responsibility for it upon those parts of the public who have continued working and received wages for this work. Slowly but surely, there is a sense that to have a steady job and to receive wages is a social sin, a forbidden pleasure [.. . ] (6 January 1940)

Many of the higher-income members avoided participating in fund-raising campaigns, a fact which severely affected the effectiveness of the campaigns. As a result the amount raised from the membership dropped from 70,030 pounds in 1936 to 48,800 in 1940 . Others chose to leave the Histadrut entirely. In 1940 alone, the leadership admitted that a thousand members left due to the fund-raising campaign held in that year. Thus, despite the fact that many unemployed new immigrants joined the federation in order to receive unemployment benefits, this period saw a drop in the growth levels of the Histadrut. ${ }^{79}$ Speaking at an internal Histadrut meeting

7 For evidence of the unrest among the unemployed, see a report on a public meeting of unemployed in the Davar newspaper, 27 March 1941, the views expressed in the opposition joumal Bamifneh, 19 November 37 and an essay by Y. Petrozeili in Bamishan (Tel Aviv, 1937). For details on the formation of the left-wing opposition within Mapai, sec Y. Ishai, Siatiyut Betnuat Haavoda (Tel Aviv, 1978), pp. 126-156; P. Merhav, The Israeli Left (San Diego, 1980), pp. 102-111; A. Shapira, Berl (Tel Aviv, 1980), pp. 496-503.

79 Evidence of the reluctance of the higher-income members to participate in the funding of the unemployment activities can be found in the drop in donations to the fund-raising campaigns, as shown in Kanev, Habituah Hasoziali, p. 106 and reflected in speeches by Golda Meir, who headed the fourth fund-raising campaign, see G. Meir, Bedegel Haavodah 
after the return to full employment, Golda Meir, who headed the mutual assistance efforts of the Histadrut, admitted that during the fundraising campaigns for the unemployment fund:

I had the feeling that if we do not find a more sophisticated way to provide mutual aid the crisis and the conditions for mutual aid will have a bad effect upon the givers, perhaps even more than upon the unemployed who receive the aid [...] There is a danger that the givers, those members who have steady jobs, will get used to seeking themselves as giving to others who have less than them. We must find a way to abolish the distinction between givers and recipients, because this distinction can have very dangerous implications. ${ }^{80}$

The outbreak of World War II and the requirements of the British war effort in Palestine brought the depression to an end in 1941. By mid-1943 the Mandatory government was contemplating reconstruction plans for the post-war period, among them the introduction of social insurance. In an attempt to influence the nature of the proposed social insurance legislation, the Histadrut leadership initiated a series of internal discussions on this issue. ${ }^{81}$ These culminated in a memorandum presented to the government's labour department in December 1945 and in a detailed plan for the social insurance system for the state-to-be published in 1948. Not unlike many other trade unions, the participants in the Histadrut internal discussions were united in their opposition to a compulsory state UI programme. In this case, alongside the more common fears of loss of control over this sphere of union activity, there also existed a deep mistrust of the intentions of the Mandatory authorities. In particular, there were fears that the government would use the funds accumulated in a UI programme primarily to support unemployed Arab workers, thereby strengthening the standing of Arabs in the labour market. At the same time, there was widespread agreement on the need for govemment financial support for any prolonged efforts to alleviate unemployment and the suffering of the unemployed. The formal result of the discussions was a call upon the government to work with the unions and employers to fight against unemployment. In the more detailed Histadrut proposals, a Ghent-style system of UI was suggested, by which the government subsidized trade union-run unemployment funds. ${ }^{82}$ More interesting was the fact that beneath the common

(Tel Aviv, 1972), pp. 51-59. Also see Z. Stemhell, Binyan Uma O Tikun Hevrati (Tel Aviv, 1995), pp. 386-399.

${ }^{80}$ See Meir, Bedegel Haavodah, p. 52.

${ }^{81}$ See Department of Labour, Annual Report for 1945 (Jerusalem, 1946), p. 20 and minutes of meeting of the mutual aid department of the Histadrut, 13 June 1943, Labour Archives, IV $-407-1-443$.

${ }^{82}$ The Histadrut proposal was included in a document entitled "Memorandum submitted to the director of department of labour of the Palestine government", 31 December 1945, quoted in Doron and Kramer, The Welfare State, p. 146. For the proposal for the social insurance system in Israel, see Y. Kanevsky, "Tochnit Lebituach Soziali Bemedinat Yisrael", Hikrei Avodah, 1-2 (1948). For an earlier proposal that included the Ghent-style 
position, it was already possible to identify two conflicting positions on UI within the labour movement during this period. While Yitshak Kanevsky (Kanev), the Histadrut's foremost expert on social insurance, stressed the necessity of UI and opposed a compulsory state scheme due only to the specific conditions of the Mandate, the position that was emerging among other influential figures in this debate was critical of the very idea of UI. Yitshak Finkelstein (Eylam), the director of the Histadrut unemployment fund (and soon to be the director-general of Israel's Ministry of Labour), emphasized the negative aspects of UI, in particular the fact that it contradicted the "constructive" goals of the Zionist movement and the Histadrut and that it would lead to the provision of assistance to the unemployed rather than encouraging them to return to the undertaking of productive labour. A similar position was expressed in an analysis of a proposal to adopt UI submitted to the treasurer of the Jewish Agency (and the first Minister of Finance in Israel), Eliezer Kaplan. The conclusion of the analysis was that UI was an inappropriate solution to unemployment as long as the economy was undeveloped and in flux. ${ }^{83}$

\section{UNEMPLOYMENT INSURANCE IN ISRAEL}

\section{The Debate over Compulsory State UI}

Ostensibly the establishment of the State of Israel paved the way for the introduction of compulsory state-administered UI. Not only did the threat of a mass integration of cheap Arab labour into the labour movement no longer exist (due to the exodus of most of the Arabs from Palestine) but Mapai, the party that had led the Histadrut in the pre-state period, now held state power and many of the former political leaders and officials of the Histadrut now held top government positions. Initial signs indeed indicated that UI was to be among the first social insurance programmes adopted by the first elected government. In its guidelines the new government promised to "introduce in progressive stages a system of social insurance and mutual aid institutions against unemployment". At the beginning of 1949, an interministerial committee headed by Yitshak Kanev (on loan to the new Ministry of Labour and Social Insurance) was formed by the government with a mandate to draw up a programme for social insurance in the new state. Among the goals of the committee was the provision of income maintenance for the unemployed. Indeed, when

system of UI, see Y. Kanevsky. "Tochniteinu Bebituah Soziali", Ahdut Haavodah, vol. 4 (Tel Aviv, 1946).

3 See minutes of the committee on social welfare, 24 November 1943 and 13 December 1943 (Labour Archives, IV-104-226-7 and IV-407-1-443) and letter from Dr A. Shmork to E. Kaplan, 28 December 1942 and report on the UI proposal, 3 March 1943 (Central Zionist Archives, S9 1037). 
the committee submitted its recommendations a year later, compulsory UI was included in the first stage of the proposed social insurance system. In addition, public statements dealing with social insurance issued by the Histadrut leadership reiterated the trade union's support for the adoption of UI. ${ }^{84}$ Moreover, there was a clear-cut need for a state plan for assistance to the unemployed, especially since, for all intents and purposes, the Histadrut unemployment fund had ceased functioning in the early 1940s. Within a few months of achieving independence in May 1948, there were initial signs of growing unemployment. This was primarily due to the inability of the economy to absorb the mass influx of demobilized soldiers and, in particular, new immigrants into the country. While exact figures do not exist, an internal Ministry of Labour report identified a "significant change" in the labour market situation in mid-1949, noting that there were over 23,000 job-seekers in June of that year. This number includes only those unemployed who registered at the labour exchanges of the various trade union organizations (thereby excluding the thousands of unemployed in immigrant absorption camps and the Arab population). Official figures for 1950 put the unemployment level at 11.5 per cent of the workforce. ${ }^{85}$

However, the overt support for UI expressed by the government and Histadrut did, in fact, conceal a far harsher reality. Kanev and like-minded advocates of UI within the Histadrut, the public administration and the political system, ${ }^{86}$ found themselves fighting a losing battle against a powerful coalition of political figures and government officials who were determined to prevent the inclusion of $U I$ in the social insurance programme. Initial indications of the force of this opposition can be found in the deliberations of the Kanev committee. Apart from Kanev himself, most of the other members of his committee (top officials representing various government ministries) preferred to defer the implementation of UI until the second stage of the programme. Indeed, it was only due to Kanev's insistence that UI was included in the first stage, though its introduction

st On the guidelines of the first elected government, see the Prime Minister's statement in the parliament in Divrei Haknesset, vol. 1,8 March 1949, p. 56. On the goals of the Kanev committee and its recommendations, see Tochnit Lebituach Soziali Beyisrael (Tel Aviv, 1950). After the first stage of the National Insurance Law was passed, the Histadrut generalsecretary Mordechai Namir stated that the Histadrut sought to ensure that in the future the law be widened to include among other things, insurance against unemployment (minutes of the executive bureau, 26 November 1953).

ss See report on activities of the Ministry of Labour and Social Insurance, April-June 1949, State Archives, 5444/1639. For more details on unemployment during this period and the problematic nature of the data, see A. Hovne, The Labor Force in /srael (Jerusalem, 1961). ${ }^{86}$ Among the supporters of UI were Walter Preuss, who headed the Histadrut's statistical department (W. Preuss, "Bitachon Soziali VeBituach Avtalah Bemedinat Yisrael", Hikrei Avodah, 1-2 (1948), pp. 108-115), Giora Lotan, who served as the director-general of the Ministry of Labour and Social Insurance and later was the first head of the National Insurance Institute (G. Lotan, "Bituah Avtalah", Yarhon Haavoda, 1 (1951), pp. 1-3 and a number of members of parliament from the communist party and the left-wing Mapam. 
was supposed to be delayed "for a year or two". The treasury representative, Y. Ronen, was the most outspoken of the critics of UI and insisted that his reservations regarding this programme be published in the committee's report. By the time Kanev presented his report to the government in May 1950, it was obvious to all involved that UI was not about to be adopted and thus Kanev did not even include $\mathrm{UI}$ in his estimations regarding the cost of the initial stage of the social insurance programme. When the National Insurance Law was presented to the parliament in 1951 it covered only old age, work injury and births. In fact, the adoption of a compulsory state-run UI programme in Israel would have to wait until the beginning of the 1970 s before finally being legislated. ${ }^{87}$

The fact that the adoption of UI was rejected by decision-makers during this period of growing unemployment (in contrast to other social insurance programmes) reflects both the identity of the political and administrative figures involved in the decision-making process and the influence of a number of objective and ideological factors upon them. Not coincidentally, all the individuals involved in this process were affiliated with Mapai and had played major roles in the efforts by the Histadrut and the Jewish Agency to deal with unemployment in the past. The Finance Minister, Eliezer Kaplan, was a member of the executive committee of the Histadrut which discussed establishing the unemployment fund and he served as the Jewish Agency Treasurer during the 1936-1940 depression. ${ }^{88}$ The Minister of Labour, Golda Meir, led one of the major campaigns aimed at raising funds for the unemployment fund and headed the mutual aid activities of the Histadrut. Her ministry's director-general, Yitshak Eylam, had directed the unemployment fund from its establishment. Finally, Mordechai Namir, the Histadrut secretary-general, had been the secretary of the Tel Aviv workers' council during the period of unemployment in the 1930s and was the chairman of the unemployment fund board of directors. ${ }^{89}$

The issues that the adoption of UI raised during the first years after statehood were similar to those that occupied the Mapai leadership during the depression. Once again, the question of the financial burden entailed in any effort to provide assistance to the unemployed surfaced. According to the projections of the Kanev committee, UI would cost 2,849,880 Israeli

87 See minutes of the Kanev committee, 14 August 1949, National Insurance Institute Archive, 14-2, 1-2. Ronen's reservations were published in Toclmit Lebituach, pp. 40-41. See also Kanev's report to the govemment in the minutes of the government meeting, 17 May 1950, pp. 20-41, State Archives.

* Kaplan had been actively involved in previous discussions regarding UI. Like Namir, he was a member of the committee established to examine the various UI proposals in 1931. He was an active participant in the executive bureau debate on the viability of the idea and he was, of course, very much involved in decisions regarding subsidies for the unemployment fund as Jewish Agency Treasurer. In most of thesc discussions, Kaplan had expressed serious reservations regarding the expense entailed in the project and in late 1938 had sought to end Jewish Agency support for Mishan.

Not surprisingly perhaps, Namir was appointed Minister of Labour a few years later. 
pounds during the first year of operation, 16 per cent of the cost of the first stage of the social insurance plan. ${ }^{90}$ More important, unlike many of the other programmes, it would require treasury participation to the tune of 949,960 pounds, 46 per cent of the state's contribution to the plan. Finance Minister Kaplan was particularly worried by these figures. As the person responsible for finding the resources to pay for the absorption of hundreds of thousands of new immigrants, for the establishment of the infrastructure of the new state and for its vital defence needs, he was understandably hesitant to commit himself to paying for a comprehensive social insurance programme. Indeed, he sought to delay discussion of the issue of social insurance for as long as possible. Eventually, however, he did accede to demands to adopt social insurance for the elderly, the work injured and mothers, which also required a very significant state outlay. Why then did he (and the rest of the Mapai leadership) continue to oppose UI?

A partial answer can be found in another.issue that surfaced during the previous unemployment crises - the contradiction between assistance to the unemployed, the moralistic approach to labour to which the Mapai leadership adhered, and the perceived characteristics of the unemployed. Contrary to the original intention of the founders of the unemployment fund during the $1930 \mathrm{~s}$, most of the fund's resources went to direct assistance rather than providing jobs. Moreover, despite diverse efforts to encourage the out of work to seek employment, the Histadrut leadership was convinced that many of the unemployed had in fact preferred assistance over work. While the Kanev committee proposal for UI did include references to the importance of full employment, it was clear that the programme would primarily provide money to the unemployed. This eventuality was unacceptable to the Mapai leadership at the time. It not only ran counter to its approach to labour but the notion was perceived as particularly unacceptable given the identity of most of the unemployed during this period.

Apart from demobilized soldiers, most of the unemployed after the establishment of the state were new immigrants, mainly those from Arab countries. These new immigrants comprised a very significant proportion of the hundreds of thousands of immigrants that more than doubled Israel's population during its first four years of existence. The new immigrants from Arab countries differed greatly in their looks, their culture and their beliefs from most of the more veteran Jews who lived in Israel and who were of European origin. Moreover, they lacked the qualifications, the means and the opportunities to enter the Israeli labour market successfully. Many were forced to seek unskilled work in agriculture and industry. Not surprisingly, unemployment was concentrated primarily within this social group. Thus, for example, in 1957 when the general

${ }^{90}$ See Tochnit Lebituach, p. 81. 
level of unemployment had dropped to 7.5 per cent, unemployment among new immigrants from Arab countries remained high at 12.per cent. Indeed, members of this group comprised just under 40 per cent of all the unemployed."

The Mapai leadership and the party rank and file tended to regard these immigrants as lacking the will or ability to join the workforce, as lazy by nature and ignorant of the labour values that were so central to the labour movement ideology. ${ }^{92}$ Obviously, people lacking the will or ability to work could not be allowed to receive benefits and remain at home. The Mapai leadership was loath to confront once again the traumatic experiences of the previous episodes of thousands of unemployed workers living off handouts. The preferred solution was a programme of relief work, that would provide the new immigrants with a minimal income and, at the same time, enable them to engage in physical labour. As a result, from 1950 onwards, the government initiated a large-scale workfare programme that provided employment in afforestation, archeological digs and road-building for thousands of new immigrants and, in retum, they were paid wages that were well below those of other employees. The workfare programme was regarded as a sort of "work school" through which the government enabled the new immigrants to learn work habits and become familiar with the specific conditions in Israel..$^{93}$

However, alongside the moral dilemmas faced by the Mapai leadership in the context of dealing with unemployment, it would appear that more political considerations also dictated its response to the UI proposal. The individuals involved in the decision-making process had all been intimately involved in the efforts to defuse the political implications of the previous unemployment crisis. Meir and Namir, in particular, had been at the forefront of efforts to deal with both the discontent of the unemployed and the opposition of the working members of the Histadrut to the demands made upon them to fund the activities of the unemployment fund. The mass immigration during the first years of statehood threatened to

91 In 1954, of the new immigrants from Arab countries, 27.4 per cent were employed in agriculture and an additional 23 per cent were unskilled workers in industry (M. Lissak, Social Mobility in /srael Sociery (Jerusalem, 1969), p. 18). For data on unemployment among the immigrants, see D. Patinkin, "The Isracl Economy: The First Decade", in the Falk Project for Economic Research in Israel, Fourth Report 1957 and 1958 (Jerusalem, 1959), p. 36.

92 For a study of the dominant perception of the new immigrants by the Mapai leadership, see T. Segev, 1949, Hyisraelim Hrishonim (Jerusalem, 1984), pp. 105-187. For a more theoretical discussion of this issue, see D. Bernstein, "Immigrants and Society - a Critical View of the Dominant School of Israeli Sociology", British Journal of Sociology, 31:2, (1980), pp. 246-264.

${ }_{93}$ For an explanation of the educational goals of the workfare programme, see an editorial dealing with the government employment policy in Yarhon Haavodah Vebituah Leumi, 4, 31 (1952), pp. 1-3. 
revive, with even greater intensity, these tensions. In addition to the negative perception of the characteristics of the new immigrants, the veteran Israelis of European origin feared that the influx of new immigrants would raise the tax burden and undermine their standing in the labour market by offering cheap labour. The Mapai leadership was understandably sensitive to these fears, particularly as they were being expressed by the core membership of the party and the Histadrut. Initially, the government and Jewish Agency (which had responsibility for the immigrant camps) sought to limit the impact of the immigrants on the labour market (and upon the official unemployment rate) by preventing them from leaving the camps to seek work. ${ }^{94}$ While fears of political unrest in the camps eventually required the state to allow the new immigrants to seek work, the Histadrut actively sought to limit their competition with the more veteran workers. Indeed, there were cases in which Histadrut activists formed picket lines to prevent new immigrants from undercutting wage levels by working for low wages in the agricultural and construction sectors. ${ }^{95}$

While the Histadrut sought to enlist the new immigrants, thereby enhancing its stand in the labour market and Mapai's political dominance, it virtually ignored their employment plight, preferring to focus its efforts on guaranteeing the wage levels of veteran workers and its role in the new state. ${ }^{96}$ It could afford to do so because it had alternative but effective means of enticing immigrants to join its ranks. One of these was its continuing control over the labour exchanges (which were not nationalized until the late 1950s). A far more effective tool was its health fund, Kupat Holim. Due to the fact that no national health scheme existed, Israelis were compelled to join one of a number of public health insurance schemes in order to provide for their health needs. Of these, the Histadrut fund was the largest and oldest. After the establishment of the state, an agreement was reached by which immigrants would immediately join Kupat Holim upon arrival in the country and their dues for the first three months would be paid for by the Jewish Agency. As a result of this system, membership in the health fund trebled within the first seven years following independence. However, membership in the fund also entailed automatic membership in the trade union federation. Thus membership in the Histadrut grew

\footnotetext{
See Patinkin, "The Israel Economy", pp. 30-31.

${ }^{95}$ One well publicized case occurred in the city of Petah Tikva in mid-May 1950 when workers' council and labour exchange activists prevented new immigrants in a nearby camp from leaving for work because they were willing to work for very low wages, while hundreds of veteran workers were unable to find employment: see reports in the Al Hamishmar. Davar, Maariv and Jerusalem Post newspapers, 17 May 1950.

* During the 1949-1950 period, the issue of new immigrant unemployment was not discussed at all in the meeting of the Histadrut secretariat (vaada merakezet), the central decision-making body, and only once in the executive bureau. In that discussion, the option of UI was not raised, but the possibility of renewed assistance was described as a threat to be avoided at any cost: see minutes of the executive bureau, 16 March 1949, pp. 1-18.
} 
dramatically and by 1960 it included 60 per cent of the Jewish adult population of Israel.97

\section{The Adoption of Workfare}

Clearly the introduction of UI, as proposed by the Kanev committee, would have exasperated the tensions between the employed veteran members of the Histadrut and the unemployed or underemployed new immigrants. As any other social insurance programme, UI was based on the notion of the working population subsidizing those unable to provide for themselves, in this case the unemployed. Adoption of the programme would require not only added government expenditure (thereby raising the spectre of higher taxes) but also entailed the levying of a 1 per cent insurance payment on all workers. At a period during which unemployment threatened primarily new immigrants, the additional burden was likely to generate among the working population the kind of opposition that had accompanied the fund-raising campaigns for the unemployment fund, just over a decade before. This was particularly true given the perception of the veteran Israelis that the new immigrants did not want to work and would prefer to receive unemployment benefits rather than earn their living. Workfare programmes were seen as a far better solution in that they not only overcame the moral objection to providing benefits to unmotivated new immigrants but they both created employment for the new immigrants outside of the existing labour market and did not require the direct financial participation of the employed in the effort.

Workfare programmes, coupled with efforts at vocational training, remained the mainstay of efforts to deal with the unemployed in Israel until the late $1960 \mathrm{~s}$, despite the fact that the workfare programmes were never formally legislated. During the late 1950 s, the number of participants in the workfare programme reached over ten thousand and during a brief recession in 1966-1967, the number doubled to over twenty thousand participants. ${ }^{98}$ The format of the workfare programme remained unchanged and it continued to consist of low-paid physical labour. All attempts by opposition members of parliament and social security experts to bring about a change in the Mapai position were thwarted and a series of Labour

97 For an examination of the political role of the labour exchanges and of Kupat Holim, see P.Y. Medding, The Founding of Israeli Democracy, 1948-1967 (New York, 1990), pp. 152-156, 166-171. For more on the role of the labour exchanges, see Z. Rosenhak, "Mekoroteiha Vehitpathuta Shel Medinat Revahah Dualit" (Ph.D. dissertation, Jerusalem University, 1995), pp. 73-82. For more on the Histadrut and Kupat Holim, see U. Yanay, "Service Delivery by a Trade Union: Does it Pay?", Journal of Social Policy, 19, 2 (1990), pp. 221-234. The figures on Histadrut membership are from Y. Slutzki, "The Histadrut Its History, Structure and Principles", in Avreh and Giladi, Labor and Society, p. 14.

98 Data on the workfare programme are based upon figures published in the Ministry of Labour joumal, Avoda Vebituah Leumi, 8, 154 (1962) and upon figures provided to a public committee on unemployment insurance which convened in Jerusalem in May 1970. 
Ministers stuck to the anti-UI position adopted in the early 1950s. It was only in the wake of the 1966-1967 recession and the fact that the unemployed during this period included many members of the middle classes that the policy was reconsidered, finally culminating in the introduction of compulsory state unemployment insurance in January $1973 .{ }^{99}$

\section{CONCLUSION}

This case study of the role of the Israeli labour movement in the evolution of UI underlines the difficulties entailed in comparative analysis of the history of the labour movement and its role in the development of the welfare state and social policy. While the contours of the development of the Histadrut policy vis-à-vis UI were initially similar to those of most other trade unions, in that it evolved from a trade union fund to local and national subsidies, the final stage of the process - the adoption of compulsory state UI - was delayed for a very long period at the behest of the labour movement itself. Why did the latter development of the Histadrut policy differ so sharply from that adopted by other labour movements at the time?

While ostensibly the initial development of the Histadrut's policy towards the unemployed was indeed similar to that of most other labour movements, this was only partly true of its motivation. The Histadrut was indeed concerned with the privation of its unemployed members and was worried by their reaction to prolonged unemployment. It did seek to encourage unorganized workers to join by offering them protection against the deprivation caused by the lack of employment and income, and it did try to provide a more egalitarian social structure than that created by capitalism. However, unlike other European trade unions, the Histradut was primarily motivated by nationalist goals and values. The federation adopted its union plan in reaction to the threat that unemployment presented to the continuation of the Zionist project itself. It sought to adopt "constructive" solutions to the problem of unemployment (thus endeavouring, if often unsuccessfully, to offer work rather than cash assistance to the out of work) because the Histadrut regarded a retum to labour as an integral part of the new Jewish society in Palestine that it was creating and because it sought to ensure full Jewish participation in the labour market. Finally, it initially opposed state UI due to its fears of the Mandatory government and the strengthening of Arab labour.

However, by the early 1950 s, many of the original reasons for introducing UI no longer existed. Nationalist motives, such as ensuring a Jewish presence on the labour market or preventing emigration, were no longer relevant due to the exodus of Arabs and the mass influx of Jews, who had

99 For a detailed discussion of developments surrounding the adoption of the law and subsequent changes made in it, see Gal, "The Development of Unemployment Insurance". 
no option other than to remain in Israel. The Histadrut did not need UI as a means of enticing immigrants to join the trade union federation, the health fund and control over the labour exchanges were incentives enough. Moreover, Mapai's political dominance ensured labour movement control over the economy. Thus, unlike Scandinavian unions, it also had little desire to seek the introduction of Ghent-style union unemployment funds. ${ }^{100}$ Finally, the unemployment did not affect the Histadrut's core membership but rather the new, unskilled and uninfluential immigrants.

Nevertheless, mass unemployment did exist and the Mapai political leadership was required to find a solution to the needs of the unemployed. Why was the workfare approach adopted instead of unemployment insurance and why did the labour movement leadership stick to its opposition so tenaciously and for so long? The values and perceptions of the Histadrut and Mapai leadership, as structured by their experiences with the efforts to deal with unemployment during the pre-state period, would appear to go a long way in explaining the movement's approach to unemployment insurance in the period following independence.

It is here that a historical analysis that underlines the impact of "policy legacies" can play a vital role in explaining the strangeness of the Israeli case. As a number of recent studies of different aspects of the employment policies adopted in welfare states have shown, the decision-making process is often strongly influenced by previous policy decisions and their implications. In most cases, analyses have focused upon the way in which institutions, such as labour exchanges, and the principles adopted with regard to their operation have created the boundaries of future debate on these issues. Once these frameworks exist, decision-makers tend to regard them as points of reference in the decision-making process and generally feel bound to maintain their existence. ${ }^{101}$ However, as Heclo showed in his examination of the decision-making processes in the formulation of social policy in Britain and Sweden, policy legacies are also relevant in the sense that they have a learning effect upon decision-makers, and, as Pierson notes, their impact comes from "concentrating on the efforts of politicians to understand the consequences of their own actions [...] Important political actors may become aware of problems as a result of their experiences with past initiatives. The setting of a new agenda and the design of alternative responses may build on (perceived) past successes or may reflect lessons learned from past mistakes". ${ }^{102}$ The case of the

100 This a central claim in Rothstein's analysis of the development of the Swedish unemployment insurance system ("Labor-market institutions”).

101 See D. King, Actively Seeking Work? (Chicago, 1995); B. Rothstein, "Labor-market institutions"; and M. Weir, Politics and Jobs (Princeton, 1992).

${ }_{102}$ See Heclo, Modern Social Politics, and P. Picrson, Dismantling the Welfare State? (Cambridge, 1994), pp. 41-42. For further discussion of this point, see P.A. Hall, "Policy Paradigms, Social Leaming, and the State", Comparative Politics, 25, 3 (1993), pp. 275296. 
Histadrut and unemployment insurance would appear to be a powerful example of the way in which this process of political learning works. Due to the centralized nature of the Histadrut and Mapai and the continuity of leadership in the labour movement, the same individuals dealt with unemployment policy, either directly or indirectly, from the period when unemployment first emerged as an issue and right through until the debates over UI in the decades after independence. They then had first-hand experience of the effects of the various policies implemented to deal with unemployment and the often negative implications of these efforts. These experiences, coupled with the values and perceptions of these individuals and their movement, strongly influenced their approach to unemployment in the decades following Israel's establishment. ${ }^{103}$

Unemployment insurance was rejected and workfare introduced because the decision-makers involved in the policy formulation process feared that adoption of UI would re-create the negative implications of previous attempts to deal with unemployment. They had seen the undoing of the work ethos during the 1925-1927 period, when the WZO had provided - assistance to the unemployed, and it had recurred despite all the Histadrut's efforts to the contrary, during the unemployment of the late 1930s. Given the way in which the Mapai leadership perceived the work ethics of the immigrants from Arab countries, it is not surprising that they were hesitant to return to a situation in which the unemployed would be able to receive cash benefits while doing nothing. In addition, Meir, Kaplan, Eylam and Namir were well aware of the financial implications of unemployment insurance and, in particular, the resentment that the financing of this expenditure had upon the more highly paid and secure membership of the federation. They were undoubtedly loath to return to this policy given the job security of their core membership and the friction that was already emerging between the veterans of European origin and the immigrants. Workfare provided an appealing solution to these fears. It prevented any return to a dole, requiring the unemployed to work for their benefits. It found work and provided an income for the immigrants that did not undermine the labour market positions of the veterans. Through this system, the immigrants would be engaged in "useful" labour, thereby benefiting both society and themselves and, as a result, the expenditure

${ }^{103}$ Interestingly enough, claims to this effect have been made by individuals closely involved in the implementation of unemployment policies in Israel during this period but they have not received sufficient scholarly attention. Thus, in his autobiography, Yitshak Eylam termed the unemployment fund a "laboratory" upon which the policies of the Ministry of Labour were later to be based: see Eylam, Benitivei Maase, p. 16. Giora Lotan, the director-general of the National Insurance Institute and, during the Mandatory period, the person responsible for the distribution of subsidies to Mishan and the unemployment fund, also linked the opposition of the Mapai leadership to UI to the traumas of the unemployment fund period: see G. Lotan, Income Maintenance Activities of the Histadrut: Their Delimitation with Government Programs (Jerusalem, 1970), p. 189. 
was acceptable to the working population. Not surprisingly, it was only after most of this generation of leaders was no longer actively involved in the decision-making process on unemployment policy and after unemployment began to affect the middle classes and the skilled working class, that the workfare approach was discarded and unemployment insurance, on the lines adopted in other welfare states, adopted as policy. 